SJ Quinney College of Law, University of Utah

Utah Law Digital Commons

Utah Law Faculty Scholarship

Utah Law Scholarship

$4-2018$

\title{
The Control of Methane and Voc Emissions from Oil and Gas Operations in the Western United States
}

Arnold W. Reitze Jr.

S.J. Quinney College of Law, University of Utah

Follow this and additional works at: https://dc.law.utah.edu/scholarship

Part of the Energy and Utilities Law Commons, Environmental Law Commons, and the Natural Resources Law Commons

\section{Recommended Citation}

Reitze, Arnold W., The Control of Methane and Voc Emissions from Oil and Gas Operations in the Western United States (March 2018). Idaho Law Review, Vol. 54, No. 213, 2018.

This Article is brought to you for free and open access by the Utah Law Scholarship at Utah Law Digital Commons. It has been accepted for inclusion in Utah Law Faculty Scholarship by an authorized administrator of Utah Law Digital Commons. For more information, please contact valeri.craigle@law.utah.edu. 


\title{
THE CONTROL OF METHANE AND VOC EMISSIONS FROM OIL AND GAS OPERATIONS IN THE WESTERN UNITED STATES
}

\author{
Arnold W. Reitze, Jr.
}

Arnold W. Reitze, Jr., The Control of Methane and VOC Emissions from Oil and Gas Operations in the Western United States, 54 IDAHO L. REV. 213 (2018). 


\title{
THE CONTROL OF METHANE AND VOC EMISSIONS FROM OIL AND GAS OPERATIONS IN THE WESTERN UNITED STATES
}

\author{
ARNOLD W. REITZE, JR.*
}

ABSTRACT

This article discusses the regulation of hydrocarbon emissions, including the emissions of methane, a potent greenhouse gas, from the oil and gas industry in the western United States. It covers the regulations of the Environmental Protection Agency, the Bureau of Land Management, and other Federal agencies. It also discusses the state laws of the major oil and gas producing western states: California, Colorado, New Mexico, Utah, and Wyoming. It covers operations on public, state, and private lands, but it does not cover oil and gas operations on Indian lands that are the subject of the author's previous article. ${ }^{1}$

\section{TABLE OF CONTENTS}

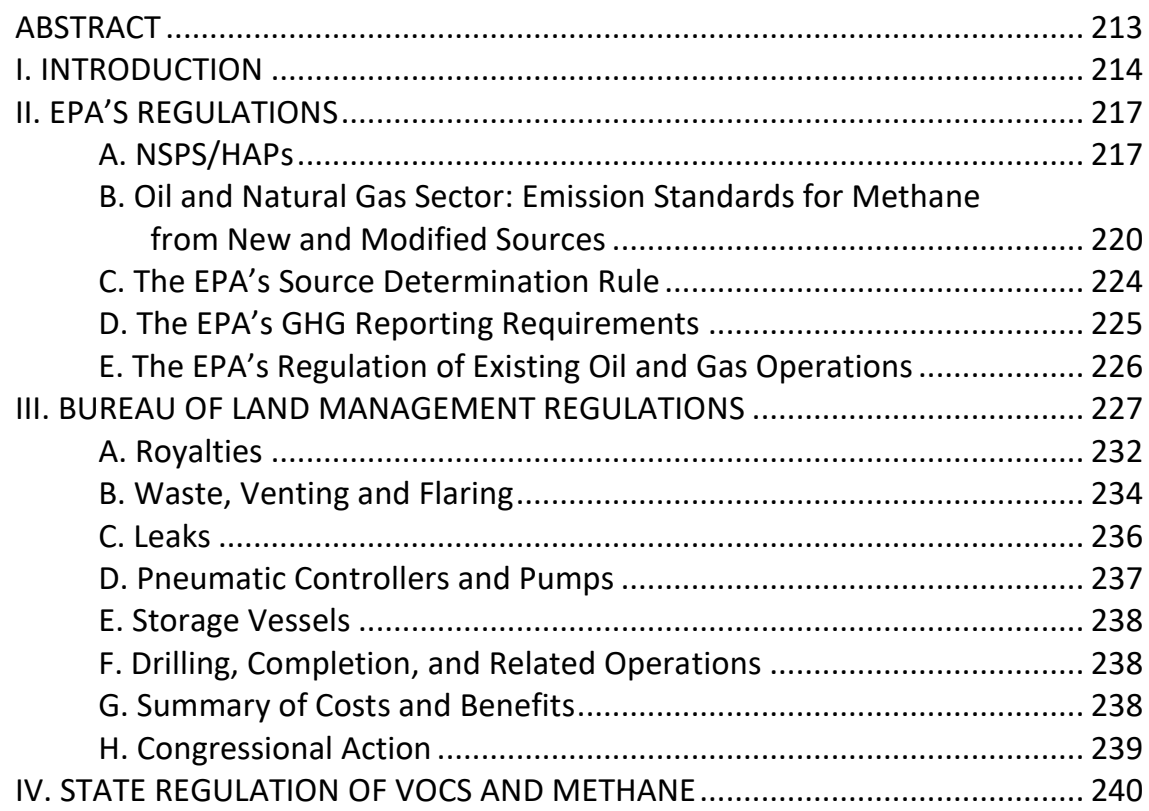

* Professor of Law, S.J. Quinney College of Law, The University of Utah. Member of the Utah Air Quality Board. Research assistance was provided by J.D. candidate Angeline Portel. This research was supported by the Albert and Elaine Borchard Fund for Faculty Excellence. The author wishes to thank Jay P. Morris, Program Manager for Minor Source Compliance Section, and Alan Humpherys, Program Manager, Minor New Source Review, Utah Division of Air Quality as well as Thomas Mitchell, Senior Counsel, State of Utah, School and Institutional Trust Lands Administration for their assistance. Michael E. Stern, J.D., LL.M, P.E. provided many useful suggestions. All opinions are solely the view of the author.

1. Arnold W. Reitze, Jr., The Control of Air Pollution on Indian Reservations, 46 ENVTL. L. 893 (2016). 


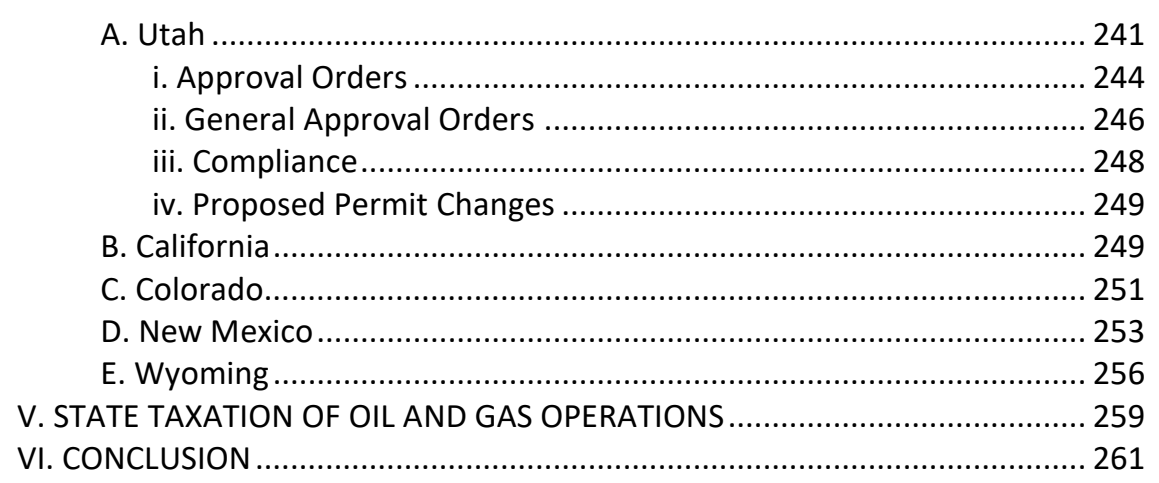

\section{INTRODUCTION}

Methane is produced biologically in ruminants (animals with a four-part stomach) and is generated in landfills and by waste handling. ${ }^{2}$ However, this article focuses on methane as the principal component of natural gas. ${ }^{3}$ Methane is one of several non-reactive hydrocarbons. Most hydrocarbons are chemically reactive and are called volatile organic compounds (VOCs). The Environmental Protection Agency's (EPA) regulations exclude methane from VOC designation. ${ }^{4}$ VOC emissions are regulated by the Clean Air Act (CAA) because they play a significant role in the creation of photochemical oxidants, which are regulated by the ozone standards. ${ }^{5}$ In addition to the general emission requirements used to improve ambient air quality, VOCs from specific operations may be regulated by new source performance standards (NSPS) ${ }^{6}$ and by national emissions standards for hazardous air pollutants (NESHAPs). ${ }^{7}$ Measures aimed at controlling VOCs also result in the reduction of non-reactive chemical emissions, such as methane, that are emitted along with VOC emissions. In recent years concern over climate change has led to attention being directed at controlling methane emissions because methane is a potent greenhouse gas (GHG). ${ }^{8}$ It is also subject to photo-oxidation that produces tropospheric ozone pollution, a conventional pollutant. ${ }^{9}$

From about 1750 to 2015 , global concentrations of methane have increased by $162 \% .{ }^{10}$ Worldwide, methane is responsible for about $20 \%$ of the global

2. Cal. Envtl. Prot. Agency Air Res. Bd., Short-lived Climate Pollutant Reduction Strategy 42 (2017) [hereinafter SHORT-LIVEd CLIMATE POLLUTANT REDUCTION STRATEGY].

3. Id.

4. 40 C.F.R. $\S 51.100(s)(1)(2017)$.

5. 40 C.F.R. $\S \S 50.9-.10$ (2017).

6. Clean Air Act $\S 111,42$ U.S.C. $\S 7411$ (2012).

7. 42 U.S.C. $\S 7412$.

8. Harro van Asselt, Interlinkages Between Climate Change, Ozone Depletion, and Air Pollution: The International Legal Framework, in CLIMATE CHANGE LAW 286, 288 (Daniel A. Farber \& Marjan Peters eds., 2016).

9. Short-Lived Climate Pollutant Reduction StRategy, supra note 2, at 42.

10. U.S. ENVTL. PROT. AgENCY, EPA 430-P-17-001, INVENTORY OF U.S. GREENHOUSE GAS EMISSIONS AND SINKS: 1990-2015, ES-2 (2017) [hereinafter INVENTORY OF U.S. GREENHOUSE GAS EMISSIONS AND SINKS]. 
warming. ${ }^{11}$ Methane emissions are $10 \%$ of the U.S. GHG emissions. ${ }^{12}$ However, from 1990 to 2015, total U.S. emissions of methane have decreased by $16 \% .{ }^{13}$ Agricultural animal operations (enteric fermentation) were the source of $25.4 \%$ of U.S. GHG emissions in 2015. ${ }^{14}$ Natural gas operations were responsible for $24.43 \% .{ }^{15}$ Petroleum systems emitted $6.1 \%$ of the methane in $2015 .{ }^{16}$ Overall, the energy sector was responsible for $42 \%$ of the methane emissions in $2015 .{ }^{17}$ However, a 2017 study from Purdue University suggests that methane emissions from power plants and refineries have been significantly underestimated. ${ }^{18}$

Carbon dioxide $\left(\mathrm{CO}_{2}\right)$ is responsible for $82.2 \%$ of the U.S. GHG emissions, ${ }^{19}$ but methane and nitrous oxide are also important GHGs. ${ }^{20} \mathrm{GHGs}$ are expressed as carbon dioxide equivalents $\left(\mathrm{CO}_{2 e}\right)$ based on their global warming potential (GWP). ${ }^{21}$ The GWP of a GHG is determined by estimating the radiative force of a gas and its expected residency time in the atmosphere. ${ }^{22} \mathrm{CO}_{2}$ has a relatively low instantaneous radiative force, but it remains in the atmosphere for 100 years or more. ${ }^{23}$ The GWP of $\mathrm{CO}_{2}$ is based on a 100 -year time horizon and $\mathrm{CO}_{2}$ is denoted as 1 ; methane $\left(\mathrm{CH}_{4}\right)$ is 25 ; nitrous oxide $\left(\mathrm{N}_{2} \mathrm{O}\right)$ is 298 ; hydrofluorocarbons have a GWP that ranges from 124 to 14,800; perfluorocarbons have a GWP that ranges from 8,860 to 12,200 ; and sulfur hexafluoride $\left(\mathrm{SF}_{6}\right)$ is $22,800 .{ }^{24}$ However, the atmospheric lifetime of methane is much shorter than carbon dioxide, and if a twenty-year timespan is used the GWP would be between 72 to $84 .{ }^{25}$ The Intergovernmental Panel on Climate Change (IPCC) publishes and updates the GWP of GHGs. The weight of a GHG times its GWP gives its $\mathrm{CO}_{2 e}$, which is usually expressed in tera grams $(\mathrm{Tg})$ (or million metric tons) of $\mathrm{CO}_{2 \mathrm{e} .}{ }^{26}$

Petroleum systems, which include production, transportation, and refining, are the source of nearly $15 \%$ of the U.S. methane emissions. ${ }^{27}$ Production-related emissions account for approximately $98 \%$ of the petroleum industry's methane emissions, and about $85 \%$ of these emissions are due to the venting of methane. ${ }^{28}$ Production emissions come from "pneumatic controllers, offshore oil platforms,

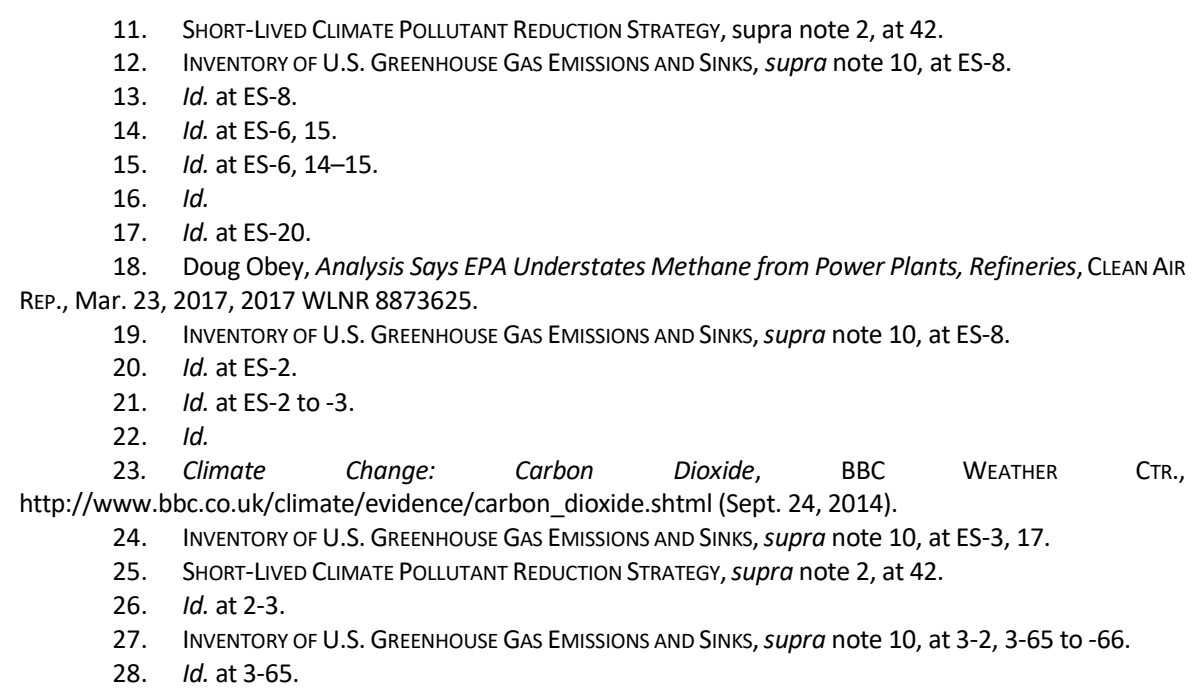


associated gas venting and flaring, gas engines, chemical injection pumps, oil tanks, hydraulically fractured oil well completions, and fugitives from oil wellheads." 29 Venting from pneumatic controllers accounts for approximately $85 \%$ of production related methane emissions. ${ }^{30}$ In 2015, methane emissions from production decreased about $8 \%$ from 2014 , with most of the reduction attributable to the control of venting and flaring. ${ }^{31}$ Transportation activities are responsible for only $1 \%$ of the methane emissions and refining operations account for only $2 \%{ }^{32}$

In 2015, the U.S. natural gas systems were comprised of 440,496 wells, ${ }^{33}$ hundreds of processing facilities, and more than a million miles of pipelines. ${ }^{34}$ About $57 \%$ of the methane emitted by the energy sector comes from natural gas operations. ${ }^{35}$ Methane is released from wells and well-site gas treatment. ${ }^{36}$ The production phase also includes releases from the gathering and boosting operations that receive natural gas and transfer it via gathering pipelines to transmission pipelines or processing facilities. ${ }^{37}$ About $65 \%$ of the methane is emitted during the production stage. ${ }^{38}$ From 1900 to 2015 , there was a 51\% increase in productionrelated methane emissions and were primarily from increases in production. ${ }^{39}$

Natural gas must be processed to create pipeline quality gas by removing natural gas liquids and other constituents from raw gas. ${ }^{40}$ Processing plants release about $7 \%$ of the methane. ${ }^{41}$ Methane emissions from processing decreased by $48 \%$ from 1990 to 2015 because emissions from equipment leak, compressor leaks, and venting are better controlled. ${ }^{42}$ Transmission and storage account for about $21 \%$ of the methane emissions from the natural gas systems. ${ }^{43}$ Methane emissions from transmission and storage "decreased by 42 percent from 1990 to 2015 due to reduced compressor station emissions . . . ."44 Distribution of natural gas involves reducing the high-pressure gas in the distribution pipelines so that it can be delivered to customers. ${ }^{45}$ There are $1,274,976$ miles of distribution mains, which are responsible for about $7 \%$ of the methane emissions from natural gas systems. ${ }^{46}$

\footnotetext{
29. Id.

30. Id. at 3-65 to -66 .

31. Id.

32. Id. at 3-65 to -66 .

33. Memorandum from the U.S. Envtl. Prot. Agency on Inventory of U.S. Greenhouse Gas Emissions and Sinks 1990-2014: Revisions Under Consideration for Natural Gas and Petroleum Systems Production Emissions 14 (Jan. 2017), https://www.epa.gov/sites/production/files/201701/documents/2017_ghgi_ngpetro_revunderconsid-production_and_gb_1.10.17.pdf.

34. INVENTORY OF U.S. GREENHOUSE GAS EMISSIONS AND SINKS, supra note 10, at 3-77.

35. Id. at 3-3.

36. See id. at 3-72.

37. See Natural Gas STAR Program: Overview of the Oil and Natural Gas Industry, EvNTL. PROT. AGENCY, https://www.epa.gov/natural-gas-star-program/overview-oil-and-natural-gas-industry (last visited Jan. 9, 2018).

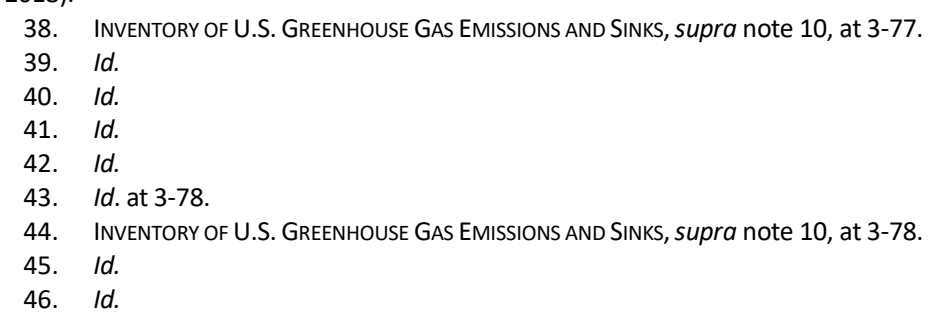


Methane emissions from distribution decreased by $75 \%$ since $1990 .{ }^{47}$ It is worth emphasizing that methane emissions from the production of natural gas dominates these emissions from natural gas systems. ${ }^{48}$

\section{EPA'S REGULATIONS}

The regulations applicable to oil and gas operations include the EPA's NSPS for the oil and gas industry, discussed below, and NSPS for specific equipment including compression ignition and spark ignition engines.$^{49}$ Oil and gas facilities must also comply with the EPA's NESHAPs such as the rule for reciprocating internal combustion engines used in their operations. ${ }^{50}$ Oil and Gas operations on public lands and Indian lands require an Application for a Permit to Drill (APD) to be submitted and approved by the Bureau of Land Management (BLM). ${ }^{51}$ Moreover, there are additional voluntary programs for the oil and gas industry aimed at reducing their air pollution emissions. ${ }^{52}$ These programs, including the Coalbed Methane Outreach Program, are in danger of being eliminated by the Trump Administration. ${ }^{53}$ Oil and gas operations are subject to additional regulation by the states. ${ }^{54}$ It is important to recognize the EPA's role in regulating GHGs is subject to change because of its Administrator, Scott Pruitt, opposes many federal regulations impacting the oil and gas industry. ${ }^{55}$

\section{A. NSPS/HAPS}

The EPA first listed oil and gas production facilities as a priority for the promulgation of NSPS in $1979 .{ }^{56}$ In 1985 , the EPA promulgated NSPS for natural gas processing plants aimed at controlling VOC emissions from leaking components. ${ }^{57}$ Later that year the EPA regulated sulfur dioxide $\left(\mathrm{SO}_{2}\right)$ emissions from natural gas processing plants. ${ }^{58}$ In 2012, the EPA expanded its coverage of the oil and gas industry with the promulgation of its NSPS/HAP regulation for the Crude Oil and

47. Id. at 3-78 tbls.3-49 \& 3-50.

48. Id. at 3-73 tbl.3-48.

49. See generally Standards of Performance for Stationary Compression Ignition and Spark Ignition Internal Combustion Engines, 76 Fed. Reg. 37,954 (June 28, 2011) (codified at 40 C.F.R. pts. 60, 1039, $1042,1065,1068)$.

50. See generally 40 C.F.R. pt. 63, subpt. ZZZZ (2017).

51. 25 U.S.C. § 396d (2012); 43 C.F.R. pt. 3160, subpt. 3162 (2017).

52. See Bridget DiCosmo, EPA Scales Back Voluntary Methane Control Program, Piquing Advocates, CLEAN AIR REP., Feb. 11, 2016, 2016 WLNR 4098884

53. Doug Obey, Former EPA Officials Warn Climate Budget Cuts Might Hurt Other Programs, CLEAN AIR ReP., Apr. 6, 2017, 2017 WLNR 10470035.

54. See infra Part IV.

55. See, e.g., Abby Smith et al., Pruitt Denies CO2 'Primary' Cause of Warming, Spurring Sharp Criticism, CLEAN AIR ReP., Mar. 23, 2017, 2017 WLNR 8873705.

56. Priority List and Additions to the List of Categories of Stationary Sources, 44 Fed. Reg. 49, 222 (Aug. 21, 1979) (codified at 40 C.F.R. pt. 60).

57. Standards of Performance for New Stationary Sources; Equipment Leaks of VOC From Onshore Natural Gas Processing Plants, 50 Fed. Reg. 26, 122 (June 24, 1985) (codified at 40 C.F.R. pt. 60).

58. Standards of Performance for New Stationary Sources; Onshore Natural Gas Processing $\mathrm{SO} 2$ Emissions, 50 Fed. Reg. 40,158 (Oct. 1, 1985) (codified at 40 C.F.R. pt. 60). 
Natural Gas Production and Onshore Natural Gas Processing Plant source category. ${ }^{59}$ The EPA's rule was based on regulations previously promulgated by Colorado and Wyoming. ${ }^{60}$ In 2013 and 2014, the EPA amended the NSPS to improve implementation. ${ }^{61}$

The 2012 NSPS applies to well completions, pneumatic controllers, equipment leaks from natural gas processing plants, sweetening units at natural gas processing plants, compressors, and storage vessels that began construction, modification, or reconstruction after August 23, 2011. ${ }^{62}$ Well completions after January 1, 2015, are subject to the NSPS during the flowback period after hydraulic fracturing operations at gas wells. ${ }^{63}$ "These completions include those conducted at newly drilled and fractured wells, as well as completions conducted following refracturing operations that may occur at various times over the life of the well." 64 The NSPS also applies to onshore sweetening units that process natural gas from onshore or offshore wells. ${ }^{65}$

The NSPS for the Crude Oil and Natural Gas Production source category sets performance standards that limit "[VOC] emissions from gas wells, centrifugal compressors, reciprocating compressors, pneumatic controllers, storage vessels and leaking components at onshore natural gas processing plants, as well as sulfur dioxide $\left(\mathrm{SO}_{2}\right)$ emissions from onshore natural gas processing plants." 66 The rule regulates onshore wells drilled principally for the production of natural gas, but it does not regulate wells drilled principally for the production of crude oil. ${ }^{67}$ Fractured and refractured gas wells are required to use reduced emissions completions, "also known as 'RECs' or 'green completions,' to reduce VOC emissions." 68 This may involve the use of a combustion device to limit VOC emissions. ${ }^{69}$

For example, individual storage vessels in the oil and natural gas production segment and the natural gas processing, transmission, and storage segments must

59. Oil and Natural Gas Sector: New Source Performance Standards and National Emission Standards for Hazardous Air Pollutants Reviews, 77 Fed. Reg. 49,490 (Aug. 16, 2012) (codified at 40 C.F.R. pt. 60, subpt. O0OO; 40 C.F.R. pt. 63, subpts. HH \& HHH). Amendments and correction of technical errors were made at, Oil and Natural Gas Sector: Reconsideration of Additional Provisions of New Source Performance Standards, 79 Fed. Reg. 79,018 (Dec. 31, 2014) (codified at 40 C.F.R. pt. 60).

60. Jana B. Milford, Out in Front? State and Federal Regulation of Air Pollution Emissions from Oil and Gas Production Activities in the Western United States, 55 NAT. RESOURCES J. 1, 11 (2014).

61. Oil and Natural Gas Sector: Reconsideration of Certain Provisions of New Source Performance Standards, 78 Fed. Reg. 58,416 (Sept. 23, 2013) (codified at 40 C.F.R. pt. 60); Oil and Natural Gas Sector: Reconsideration of Additional Provisions of New Source Performance Standards, 79 Fed. Reg. 79,018 (Dec. 31, 2014) (codified at 40 C.F.R. pt. 60).

62. See generally Energy Info. Admin., Off. Oll \& Gas, Natural Gas Processing: The Crucial Link Between Natural Gas Production and Its Transportation to Market (2006).

63. Oil and Natural Gas Sector: New Source Performance Standards and National Emission Standards for Hazardous Air Pollutants Reviews, 77 Fed. Reg. 49,490, 49,493 (Aug. 16, 2012) (codified at 40 C.F.R. pt. 60 , subpt. $0000 ; 40$ C.F.R. pt. 63 , subpts HH \& HHH).

64. Id.

65. $\quad l d$.

66. Id. at 49,492 .

67. $I d$.

68. Id.

69. Oil and Natural Gas Sector: New Source Performance Standards and National Emission Standards for Hazardous Air Pollutants Reviews, 77 Fed. Reg. 49,490, 49,492 (Aug. 16, 2012) (codified at 40 C.F.R. pt. 60 , subpt. OOOO; 40 C.F.R, pt. 63, subpts HH \& HHH). 
achieve at least $95.0 \%$ emissions reduction if their VOC emissions are equal to or greater than six tons per year (tpy). ${ }^{70}$ Pneumatic controllers located between the wellhead and the point at which the gas enters the transmission and storage segment have natural gas bleed limits. ${ }^{71}$ Pneumatic controllers are used to open or close valves, control liquid levels, control temperature, or control pressure. They usually are powered by natural gas, which results in venting each time the controller is activated..$^{72}$ Therefore, they constitute a release pathway that must be included in a methane control program. Centrifugal compressors also have VOC reduction requirements. ${ }^{73}$ In addition, the NSPS impose requirements for leak detection and repair (LDAR) and $\mathrm{SO}_{2}$ emissions on onshore natural gas processing plants. ${ }^{74}$

Oil and natural gas production facilities were listed as source categories pursuant to CAA $\S 112$ in $1992 .{ }^{75}$ Transmission and storage facilities were added in 1998. ${ }^{76}$ National Emissions Standards for Hazardous Air Pollutants (NESHAPs) were established in 1999 for major sources of hazardous air pollutants (HAPs). ${ }^{77}$ In 2007, benzene emissions from tri-ethylene glycol dehydration units were included in the NESHAP. ${ }^{78}$ In 2012, the EPA revised and strengthened the NESHAP for the Oil and Natural Gas Production source category and the Natural Gas Transmission and Storage source category. ${ }^{79}$

The EPA has established maximum achievable control technology (MACT) standards for specified emission sources in the oil and gas industry. ${ }^{80}$ Major sources at oil and natural gas production facilities may be subject to the NESHAP for glycol dehydration units, which includes MACT standards for "small" glycol dehydration units that include specific limits for benzene, toluene, ethylbenzene, and xylene (BTEX). ${ }^{81}$

The 2012 NSPS for crude oil and natural gas production did not include emission standards for methane; the EPA expected that the NSPS regulation of

70. Id.

71. Id.

72. U.S. GOV'T ACCOUNTABILITY OFF., GAO-16-607, OIL AND GAS: INTERIOR COULD DO MORE TO ACCOUNT FOR AND MANAGE NATURAL GAS EMISSIONS 6 fig.1 (2016) [hereinafter GAO]

73. Oil and Natural Gas Sector: New Source Performance Standards and National Emission Standards for Hazardous Air Pollutants Reviews, 77 Fed. Reg. 49,490, 49,492 (Aug. 16, 2012) (codified at 40 C.F.R. pt. 60, subpt. OOOO; 40 C.F.R. pt. 63, subpts HH \& HHH).

74. Id.

75. See Initial List of Categories of Sources Under Section 112(c)(1) of the Clean Air Act Amendments of 1990, 57 Fed. Reg. 31,576 (July 16, 1992).

76. See generally National Emission Standards for Hazardous Air Pollutants; Revision of List of Categories of Sources and Schedule for Standards Under Section 112 of the Clean Air Act, 63 Fed. Reg. 7155 (Feb. 12, 1998).

77. See generally National Emission Standards for Hazardous Air Pollutants: Oil and Natural Gas Production and National Emission Standards for Hazardous Air Pollutants: Natural Gas Transmission and Storage, 64 Fed. Reg. 32,610 (June 17, 1999) (codified at 40 C.F.R. pt. 63).

78. See generally National Emission Standards for Hazardous Air Pollutants for Source Categories from Oil and Natural Gas Production Facilities, 72 Fed. Reg. 26-01 (Jan. 3, 2007) (codified at 40 C.F.R. pt. 63).

79. See Oil and Natural Gas Sector: New Source Performance Standards and National Emission Standards for Hazardous Air Pollutants Reviews, 77 Fed. Reg. 49,490, 49,501-04 (Aug. 16, 2012) (codified at 40 C.F.R. pt. 60, subpt. OOOO; 40 C.F.R. pt. 63, subpts. HH \& HHH).

80. Id. at $49,491-49,492$.

81. Id. at 49,492 . 
VOCs would result in methane reduction as a "co-benefit." 82 Because methane is emitted with VOCs, ${ }^{83}$ the controls on VOCs emissions would lead to an annual reduction of one million tons of methane. ${ }^{84}$

\section{B. Oil and Natural Gas Sector: Emission Standards for Methane from New and Modified Sources}

On September 18, 2015, the EPA proposed amendments to the NSPS for the oil and gas sources category to expand the coverage of oil and gas VOC emissions to include controls on methane emissions. ${ }^{85}$ The EPA finalized the proposed rule on June 3, 2016. ${ }^{86}$ The EPA regulation of methane emissions from oil and gas wells was challenged by North Dakota in the D.C. Circuit on July 15, $2016 .{ }^{87}$ Fourteen states then joined the lawsuit as well as numerous industry organizations. ${ }^{88}$ Subsequently, nine states and numerous environmental groups intervened to support EPA's CAA $\S 111$ (b) rule. ${ }^{89}$ The methane rule is controversial because compliance costs are estimated at $\$ 530$ million. ${ }^{90}$ The cases were consolidated on January 4,2017 , and are discussed in section 2(B) below.

The NSPS are applicable to new, reconstructed, and modified oil and gas operations. ${ }^{91} \mathrm{~A}$ major weakness of the EPA's regulatory approach is that it does not apply to existing oil and gas operations, although the EPA could regulate existing sources either under CAA $\S 111(\mathrm{~d})$ or through State Implementation Plan (SIP) amendments required in ozone nonattainment areas. ${ }^{92}$ The amendments impose standards for GHGs and VOCs and add requirements applicable to operations and equipment covered by the 2012 standards. ${ }^{93}$ These implementation improvements do not change the requirements for operations and equipment covered by the

\footnotetext{
82. Id. at 49,513 .

83. Id. at 49,539 .

84. Id. at 49,533 .

85. See generally Oil and Natural Gas Sector: Emission Standards for New and Modified Sources, 80 Fed. Reg. 56,593 (proposed Sept. 18, 2015) (codified at 40 C.F.R. 60).

86. See generally Oil and Natural Gas Sector: Emission Standards for New and Modified Sources, 81 Fed. Reg. 35,824 (June 3, 2016) (amending 40 C.F.R. pt. 60, subpt. 0000 and proposing new standards at subpt. 0000a).

87. See Anthony Adragna, North Dakota First to Sue EPA Over Methane Regulations, DAlLY ENv'T REP. (BNA), July 19, 2016, BLOOMBERG LAW, DEN Issue No. 138.

88. Anthony Adragna, Additional Lawsuits Challenge EPA's Methane Rule, DAILY ENV'T REP. (BNA), Aug. 3, 2016, BLOOMBERG LAW, DEN Issue No. 149.

89. Anthony Adragna, EPA Gets High-Profile Backers in Methane Legal Battle, ENV'T REP. (BNA), Aug. 16, 2016, BLOOMBERG LAW, DEN Issue No. 159.

90. Hayden S. Baker, BNA Insights: EPA Resolves Scope of Federal Oil \& Gas Air Permitting Authority as It Braces for Battle Over Greenhouse Gas Regulation, Toxics L. REP. (BNA), Oct. 20, 2016, BLOOMBERG LAW, TXLR Issue No. 41.

91. Oil and Natural Gas Sector: Emission Standards for New and Modified Sources, 81 Fed. Reg. $35,824,35,827$ (June 3, 2016) (amending 40 C.F.R. pt. 60, subpt. 0000 and proposing new standards at subpt. OOOOa). 86

92. Carlos R. Romo \& Nicholas Graham, EPA Regulation of Existing Oil \& Gas Sources: Immediate and Long-Term Challenges, DAILY REP. FOR EXECUTIVES (BNA), Sept. 28, 2015, DER ISSUE No. 187.

93. Oil and Natural Gas Sector: Emission Standards for New and Modified Sources, 81 Fed. Reg. $35,824,35,825-27$ (June 3, 2016) (amending 40 C.F.R. pt. 60 , subpt. 0000 and proposing new standards at subpt. OOOOa). 86
} 
current standards at 40 C.F.R. part 60 , subpart 0000 and 0000a. ${ }^{94}$ Specifically, the amendments apply to hydraulically fractured oil well completions, pneumatic pumps, and fugitive emissions from well sites and compressor stations that are not regulated by the 2012 rules; hydraulically fractured gas well completions and equipment leaks at natural gas processing plants that are currently regulated for VOC emissions are now subject to GHG regulations. ${ }^{95}$

The 2016 rule adds new requirements for detecting and repairing leaks at natural gas well sites. Leaks, known as fugitive emissions, must be repaired within thirty days, but if a repair would shut down production then additional time for the repair is allowed. ${ }^{96}$ Leak monitoring plans must be developed using optical gas imaging equipment or by using a portable VOC monitoring instrument as specified in EPA's Method 21. ${ }^{97}$ The leak monitoring will apply to "valves, connectors, pressure relief devices, open-ended lines, flanges, compressors," and other components. ${ }^{98}$ However, some wellheads that contain only "Christmas trees" are exempt. ${ }^{99}$ The rule also adds new requirements for diaphragm pumps used at well sites. $^{100}$

The amendments to the NSPS rule also require a monitoring plan to be developed and implemented to control leaks at gathering and boosting compressor stations that obtain gas from multiple wells and move it to a natural gas processing plant. ${ }^{101}$ Because the best system for reducing methane is the same as is used to reduce VOC emissions, the requirements for centrifugal and reciprocating compressors, pneumatic controllers, and storage tanks continue to be regulated by the 2012 NSPS. ${ }^{102}$ However, the 2016 update limits methane and VOC emissions from wet seal centrifugal compressors used in the oil and gas industry, except for those located at well sites. ${ }^{103} \mathrm{~A} 95 \%$ reduction of methane and VOC emissions is required by utilizing either flaring or by routing captured gas back to the processor. ${ }^{104}$ Dry seal centrifugal compressors are not covered by the final rule because their methane and VOC emissions are small. ${ }^{105}$ Reciprocating compressors, except for those located at well sites, are to have the rod packing replaced based on specified hours of operation or elapsed calendar months or by routing emissions from the rod packing through a closed vent system under negative pressure to be

\footnotetext{
94. Id. at 35,825 .

95. See id.

96. U.S. Envtl. Prot. Agency, Summary of Requirements for Processes and Equipment at Natural GAS WeLL SITES 1 (2016).

97. Id.

98. Id.

99. Id. at 2 ("Christmas Tree" is a vertical assembly of mechanical devices at an oil or gas wellhead used primarily to control flow, which has a shape roughly resembling a Christmas tree).

100. Id.

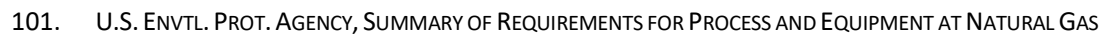
Production Gathering and Boosting Stations 1-2 (2016).

102. Id. at 2.

103. U.S. ENVTL. Prot. AgenCY, SUMmary of REQUIREMENTS OR EqUIPMENT AT NATURAL GAS TRANSMISSION COMPRESSOR STATIONS 1 (2016) [hereinafter NATURAL GAS TRANSMISSION COMPRESSOR STATIONS].

104. Id.

105. Id. (Dry seals have little leakage when they are functioning properly but when they fail emissions increase significantly, which means monitoring of seal condition is needed).
} 
reused or recycled. ${ }^{106}$ Pneumatic controllers powered by high-pressure natural gas are used to maintain liquid levels, pressure, and temperature ${ }^{107}$ Continuous bleed pneumatic controllers now have a natural gas bleed rate limit of six standard cubic feet per hour (scfh). ${ }^{108}$ Low-bleed controllers with a gas bleed rate of six scfh or less have no new requirements. ${ }^{109}$ The EPA did not finalize requirements for pneumatic pumps at compressor stations. ${ }^{110}$ Storage tanks also do not have new requirements but continue to be regulated by the 2012 NSPS requirements. ${ }^{111}$

Natural gas processing plants have new requirements for controlling emissions from pneumatic pumps. ${ }^{112}$ Natural gas-driven piston pumps are not subject to new rules, nor are diaphragm pumps powered by electricity, compressed air, or solar power. ${ }^{113}$ Processing plants continue to be regulated primarily by the 2012 NSPS. ${ }^{114}$

Requirements imposed by states (and tribes) that are at least as protective as federal requirements can be used to demonstrate compliance with the federal rule. 115 Facilities that will be subject to the EPA's standards may also be subject to current or future requirements of the Department of Interior's Bureau of Land Management (BLM), which regulates the production of natural gas on Federal lands. Therefore, the EPA and BLM will continue to coordinate their regulatory requirements. ${ }^{116}$ The BLM's program is discussed infra Part III.

In April 2017, the EPA asked the D.C. Circuit to indefinitely pause the lawsuits challenging the oil and gas NSPS due to President Trump's March 28, 2017, Executive Order on climate and energy policy that requires the EPA to immediately review agency actions that "potentially burden the safe, efficient development of domestic energy resources." 117 This Order has the potential to alter or nullify the regulation. ${ }^{118}$ In April 2017, the EPA announced it was initiating its review of the Rule and provided advanced notice of forthcoming rulemaking proceedings. ${ }^{119}$ On April 18, 2017, EPA Administrator Scott Pruitt announced the EPA would reconsider the requirement that well owners use an infrared camera to search for leaks and

106. Id. at $1-2$.

107. Id. at 2 .

108. Id.

109. NatURAl Gas Transmission Compressor Stations, supra note 103, at 2 .

110. Id. at 3 .

111. Id.

112. U.S. Envtl. Prot. Agency, Summary of Requirements for Processes ANd Equipment at Natural GAS PROCESSING PLANTS 2 (2016).

113. U.S. EnVtl. Prot. Agency, Summary of 2016 Requirements for Processes and Equipment at Natural Gas Processing Plants (2016).

114. Id. at 2 .

115. Oil and Natural Gas Sector: Emission Standards for New and Modified Sources, 81 Fed. Reg. 35,824, 37,871 (June 3, 2016) (amending 40 C.F.R. pt. 60, subpt. OOOO and proposing new standards at subpt. OOOOa). 86

116. See infra Part III.

117. David Schultz, EPA Wants Indefinite Pause on Methane Lawsuit, ENERgY \& CLIMATE ReP. (BNA), Apr. 10, 2017, BLoomberg LAW, ECR Issue No. 67; see also Exec. Order No. 13783, 82 Fed. Reg. 16093 (Mar. 31, 2017).

118. Exec. Order No. 13783, 82 Fed. Reg. 16093, supra note 117; see also Am. Petroleum Inst. v. EPA, 540 F.2d 1023 (10th Cir. 1976).

119. Lee Logan, Following Trump Order, EPA Launches Review of Oil \& Gas Methane Rule, CLEAN AIR REP., Apr. 6, 2017, 2017 WLNR 10470089. 
then document what they do. ${ }^{120} \mathrm{He}$ also responded to petroleum industry requests to stay NSPS regulations found in 40 C.F.R. Part 60 , Subpart O000a by extending the June 3, 2017 compliance deadline for Leak Detection and Repair by three months. ${ }^{121}$ On June 16,2017 , the EPA promulgated a proposed rule that would stay oil and gas NSPS for three months. ${ }^{122}$ On July 3,2017 , the D.C. Circuit held that the EPA lacked authority under the CAA to stay the final rule establishing new source performance standards for fugitive emissions of methane and other pollutants by the oil and natural gas industries, ${ }^{123}$ and it vacated the stay. ${ }^{124}$ On July 13,2017 , the D.C. Circuit granted the EPA's motion to delay enforcement of the overturned ninety-day stay to allow the Agency to seek a rehearing or appeal to the Supreme Court. ${ }^{125}$ On August 10, 2017, the full D.C. Circuit declined to review the decision that forced the EPA to enforce the oil and gas NSPS. ${ }^{126}$ The EPA also proposed a two-year delay in order to reconsider portions of the methane limits on June 16, 2017. ${ }^{127}$ That delay is also legally suspect. ${ }^{128}$ According to the Environmental Defense Fund, a delay allows "nearly 41,000 well sites, 272 compressor stations and 1,090 pneumatic pumps [to] avoid conducting leak detection and repair" as well as needing to comply with other requirements of the methane rule. ${ }^{129}$ Additional litigation over the delay is expected. ${ }^{130}$ However, the ruling concerning the ninetyday stay does not prevent the repeal of the Methane Rule if the EPA follows a proper rulemaking process. ${ }^{131}$ That proposal continues, and a hearing was held on July 10, 2017. ${ }^{132}$ At about the same time, fifteen state Attorney Generals on June 29, 2017, notified the EPA that they were prepared to sue the EPA for its

120. David Schultz, Pruitt Nibbles at Methane Rule: Are Larger Bites to Come?, ENERGY \& CLIMATE Rep. (BNA), Apr. 19, 2017, BLOOMBerg LAW, ECR Issue No. 74.

121. Id.

122. See Oil and Natural Gas Sector: Emission Standards for New, Reconstructed, and Modified Sources: Three Month Stay of Certain Requirements, 82 Fed. Reg. 27,641 (June 16, 2017) (codified at 40 C.F.R. pt. 60).

123. See generally 860il and Natural Gas Sector: Emission Standards for New and Modified Sources, 81 Fed. Reg. 35,824 (June 3, 2016) (amending 40 C.F.R. pt. 60, subpt. 0000 and proposing new standards at subpt. OOOOa).

124. Clean Air Council v. Pruitt, 862 F.3d 1, 14 (D.C. Cir. 2017).

125. Andrew Childers, Methane Emissions Standards Frozen Again as EPA Mulls Appeal, ENERGY \& CLIMATE ReP. (BNA), July 13, 2017, BLOOMBERg LAW, ECR Issue No. 134.

126. Order Denying Industry Intervenor-Respondents' and States Intervenor-Respondents' Petitions for Rehearing En Banc, Clean Air Council v. Pruitt, 862 F.3d 1 (D.C. Cir. 2017) (No. 17-1145).

127. Oil and Natural Gas Sector: Emission Standards for New, Reconstructed, and Modified Sources: Stay of Certain Requirements, 81 Fed. Reg. 27,645, 27,646 (proposed June 16, 2016) (to be codified at 40 C.F.R. pt. 60).

128. Dawn Reeves, Methane NSPS Delay Faces Same High Bar as Vacated Effort, EPA Critics Say, DAILY BRIEFING, Aug. 17, 2017, INSIDEEPA, 2017 WLNR 25393469.

129. Id.

130. Curt Barry \& Abby Smith, States Say EPA's Court Loss Proves Methane NSPS Delay Proposals Unlawful, CLeAN AIR REP., Aug. 24, 2017, 2017 WLNR 25946024.

131. Jennifer A. Dlouhy, Andrew M. Harris \& David Schultz, Court Rebukes EPA for Shelving Obama-Era Methane Regulation, ENeRGY \& CLIMATE ReP. (BNA), July 3, 2017, BLOomberg LAW, ECR Issue No. 127.

132. Catherine Douglas Moran, Environmentalists Tell EPA: Do Not Delay Methane Rule, DAlLY ENV'T REP. (BNA), July 11, 2017, BLOOMBERG LAW, DEN Issue No. 131. 
unreasonable delay in issuing methane regulations for existing oil and gas operations. ${ }^{133}$ While the methane rule's eventual status remains confused, the deadline for beginning to report emissions is October 2017, and the industry is trying to comply even though the EPA has issued no guidance. ${ }^{134}$

On November 1, 2017, the EPA raised two potential changes to the methane NSPS in notices of data availability (NODA) that were posted to EPA's website and opened for a thirty-day public comment period. ${ }^{135}$ EPA hopes to avoid additional legal challenges by characterizing the rule modifications as extensions of the 'phasein' periods for key provisions of the methane NSPS, such as the requirement that operators find and repair leaks to control fugitive emissions and the requirement that closed vent systems be certified by a professional engineer. ${ }^{136}$ EPA contends that it has authority under Section 111(b) of the CAA to extend compliance deadlines. ${ }^{137}$ The NODAs propose two compliance extensions; a three month extension that would take effect immediately, followed by a two year extension. ${ }^{138}$ Environmental groups argue there is no reasonable basis for the compliance extensions and charge the Administrator with attempting to circumvent the D.C. Circuit's ruling that the agency's 90-day stay was unlawful. ${ }^{139}$

\section{The EPA's Source Determination Rule}

The Clean Air Act's Prevention of Significant Deterioration Program (PSD) preconstruction permit requirements, the Nonattainment New Source Review (NNSR) preconstruction permit program, and the Title $V$ operating permit program apply to major sources. Major source is defined as sources in the same industrial group (the same two-digit SIC code), under common control, and located on contiguous or adjacent properties. ${ }^{140}$ On June 3, 2016, the EPA promulgated the "Source Determination Rule," which will lead to more oil and gas facilities being considered major sources rather than minor sources. ${ }^{141}$ The new rule applies to onshore oil and natural gas production and natural gas processing facilities. ${ }^{142}$ This final rule clarifies the term adjacent, which determines when minor sources are to be aggregated and treated as a major source. ${ }^{143}$ Multiple sources are to be

133. Doug Obey \& Lee Logan, States Prepare to Sue EPA for Delaying Oil and Gas Methane Controls, CLIMATE, June 30, 2017, INSIDEEPA, 2017 WLNR 20114367.

134. Abby Smith, Chevron, Encana Prepping for Methane Rule Without EPA Guidance, DAlLY Env'T Rep. (BNA), Sept. 5, 2017, BLoomberg LAW, DEN Issue No. 171.

135. EPA Floats Extended Methane NSPS 'Phase-In' as Alternative to Rule Stay, INSIDE EPA: CLEAN AIR REP. (Nov. 16, 2017), https://insideepa.com/daily-news/epa-floats-extended-methane-nsps-phasealternative-rule-stay.

136. Id.

137. Id.

138. Id.

139. Id.

140. Source Determination for Certain Emission Units in the Oil and Natural Gas Sector, 81 Fed. Reg. 35,622, 35,623 (June 3, 2016) (to be codified at 40 C.F.R. pts. 51, 52, 70 \& 71); see also 40 C.F.R. $\S \S$ 51.165(a)(1)(ii), 51.166(b)(6) (2017).

141. See generally id.

142. See generally id.

143. See generally id. 
aggregated if they are on the same site, or are on sites that share equipment and are within one-quarter of a mile of each other. ${ }^{144}$

The EPA is not requiring that EPA-approved state and local programs adopt the approach in the "Source Determination Rule." 145 This allows state and local permitting authorities that have programs approved by the EPA to continue to make source determinations for the oil and gas "industry in the manner that they believe best addresses their local air quality concerns." ${ }^{146}$ However, "states that administer PSD permitting programs under a delegation of federal authority" will have to follow the approach of the "Source Determination Rule," "or develop their own permitting programs and have them approved as a revision to a state implementation plan (SIP)." ${ }^{147}$

"The Source Determination Rule is also expected to [result in hazardous air pollutant (HAP)] reductions and will benefit areas that approach or exceed the [National Ambient Air Quality Standards (NAAQS)] for ozone." 148 "There are increasing ozone levels in areas" in the western United States that have "concentrated oil and natural gas activity, including Wyoming and Utah." ${ }^{149}$ Several VOCs emitted by sources in the oil and natural gas source category are HAPs listed under CAA $\S 112(b)$, including benzene, toluene, ethylbenzene and xylenes (this group is commonly referred to as "BTEX") and n-hexane. ${ }^{150}$

\section{The EPA's GHG Reporting Requirements}

The EPA requires oil and natural gas companies to collect and report GHG emissions data for sources emitting 25,000 metric tons per year, or more, of $\mathrm{CO}_{2 \mathrm{e}} .{ }^{151}$ The reporting requirements extend to facilities owned or operated by Indian tribes and private oil and gas operations on Indian reservations. ${ }^{152}$ Most production operations do not exceed the 25,000-ton threshold that triggers reporting requirements. Approximately 2,413 oil and natural gas facilities reported GHG emissions during 2015, but only 534 onshore production facilities reported. ${ }^{153}$ Beginning January 1, 2016, additional data "from gathering and boosting systems,

144. Id. at 35,624; see also U.S. EnVtl. Prot. Agency, Clarification of Air Permitting Rules for the OIL AND GAS INDUSTRY: FACT SHEET 1 (2016).

145. Source Determination for Certain Emission Units in the Oil and Natural Gas Sector, 81 Fed. Reg. at 35,622, 35,623.

146. Id.

147. Id.

148. Reitze, supra note 1 , at 932.

149. Id.

150. Review of New Sources and Modifications in Indian Country: Federal Implementation Plan for Managing Air Emissions from True Minor Sources Engaged in Oil and Natural Gas Production in Indian Country, 80 Fed. Reg. 56,554, 56,569 (Sept. 18, 2015) (codified at 40 C.F.R. pt. 49); see also Clean Air Act $\S$ 112(b), 42 U.S.C. § 7412(b) (2012) (listing hazardous air pollutants).

151. Mandatory Reporting of Greenhouse Gases: Petroleum and Natural Gas Systems, 75 Fed. Reg. $74,458,74,460$ (Nov. 30, 2010) (codified at 40 C.F.R. pt. 98).

152. Id. at $74,485-86 ; 40$ C.F.R. $\S 98.231$.

153. U.S. EnVtL. Prot. Agency, Greenhouse Gas Reporting Program (GHGRP), GHGRP 2015: Petroleum and Natural Gas Systems, ENVTL. PROT. AGENCY, https://www.epa.gov/ghgreporting/ghgrp-2015petroleum-and-natural-gas-systems (last visited Jan. 9, 2018). 
completions and workovers of oil wells using hydraulic fracturing, and blowdowns of natural gas transmission pipelines" must be collected and this information must be reported beginning March 31, 2017. ${ }^{154}$

Information concerning the reporting of GHG emissions from oil and gas production was promulgated on November 30, 2010. ${ }^{155}$ On January 15, 2015, the EPA proposed revisions to the GHG reporting rule. ${ }^{156}$ On May 12, 2016, the EPA issued a draft Information Collection Request (ICR) to require oil and natural gas companies to provide the information needed to regulate existing sources of methane emissions including underground storage facilities that are not currently regulated. ${ }^{157}$ This could lead to hundreds of thousands of existing oil and gas sources that emit methane being subject to new requirements. ${ }^{158}$ The EPA's ICR was criticized by the oil and gas industry and some states, which believed the ICR was the beginning of an effort to more stringently regulate existing facilities. ${ }^{159}$ On December 9, 2016, the EPA promulgated a final rule dealing with minor updates to the reporting rule. ${ }^{160}$ In March 2017 the ICR was withdrawn by EPA Administrator Scott Pruitt. ${ }^{161}$ His action has consequences because the information that was to be collected was expected to form the basis for future more stringent regulation of existing oil and gas operations. ${ }^{162}$

\section{E. The EPA's Regulation of Existing Oil and Gas Operations}

The regulation of existing oil and gas operations is primarily the responsibility of the states. ${ }^{163}$ However, if an area is designated as nonattainment, CAA section 172 (c)(1) requires a state implementation plan (SIP) to include "reasonably available control measures" including "reasonably available control technologies" (RACT) for existing emission sources. ${ }^{164}$ RACT means all those "technologically and economically feasible measures [available] that can be implemented within 4 years of . . . [a nonattainment] designation." ${ }^{\prime 165}$ RACT implementation does not constitute

154. Anthony Adragna, New Oil, Gas Greenhouse Gas Reporting Mandates Finalized, ENV'T REP. (BNA), Oct. 23, 2015, BLOOMBERG LAW, ENR Issue No. 42.

155. See Mandatory Reporting of Greenhouse Gases: Petroleum and Natural Gas Systems, 75 Fed. Reg. 74,458 (Nov. 30, 2010) (codified at 40 C.F.R. pt 98).

156. 2015 Revisions and Confidentiality Determinations for Data Elements Under the Greenhouse Gas Reporting Rule, 81 Fed. Reg. 2535 (Jan. 15, 2016) (codified at 40 C.F.R. pt. 98).

157. U.S. EnVtL. Prot. Agency, EPA's Actions to Reduce Methane Emissions from the OIL AND NATURAL GAS INDUSTRY: FINAL RULES AND DRAFT INFORMATION COLLECTION REQUEST 4 (2016).

158. See id.

159. Andrew Childers, Oil, Gas Industry Asked about Emissions Monitoring, ENv'T REP. (BNA), July 22, 2016, BLOOMBERG LAW, ENR Issue 47; Bridget DiCosmo, Energy Groups Cite Data Collection Challenges in Call for Narrow EPA ICR, CLEAN AIR REP., Aug. 11, 2016, 2016 WLNR 24334464.

160. See 2015 Revisions and Confidentiality Determinations for Data Elements Under the Greenhouse Gas Reporting Rule, 81 Fed. Reg. 89,188 (Dec. 9, 2016) (codified at 40 C.F.R. pt. 98).

161. Anthony Lacey, EPA Quickly Withdraws Oil \& Gas Methane ICR After GOP State Criticisms, CLEAN AIR ReP., Mar. 2, 2017, 2017 WLNR 7265374; David Schultz, Pruitt Kills Methane Query One Day after Request from Allies, DAlLy ENV'T REP. (BNA), Mar. 3, 2017, BLOOMBERG LAW, DEN Issue No. 41.

162. Dawn Reeves, Early Chaos Raises Doubts on Trump's Ability to Enact EPA Agenda, CLEAN AIR REP., Apr. 6, 2017, 2017 WLNR 10469943.

163. See infra Part IV.

164. 42 U.S.C. $\S 7502$ (c)(1) (2012).

165. 40 C.F.R. $\S 51.1000$ (2017). 
a complete set of measures necessary to demonstrate attainment as expeditiously as possible. ${ }^{166}$ Section 182 requires ozone nonattainment areas to include RACT for each category of VOC sources covered by Control Techniques Guidelines (CTG). ${ }^{167}$ A CTG is merely guidance, not a regulation. SIP revisions must be submitted by two years from the publication of an applicable CTG. ${ }^{168}$ EPA released its CTG for the Oil and Natural Gas Industry in 1984. ${ }^{169}$

In October 2016, the EPA updated its CTG with RACT recommendations for storage vessels, pneumatic controllers, pneumatic pumps, compressors, equipment leaks, and fugitive emissions. ${ }^{170}$ The cost of compliance is significant. For example, vapor recovery units to reduce VOC emissions for the Oil and Natural Gas Industry from each storage vessels will cost over $\$ 100,000 .{ }^{171}$

\section{BUREAU OF LAND MANAGEMENT REGULATIONS}

The Bureau of Land Management (BLM), within the Department of the Interior, was created in 1946 when the Grazing Service, which managed grazing on public lands, was merged with the General Land Office. ${ }^{172}$ It carries out the regulatory duties of the Secretary of the Interior in regard to about 258 million surface acres ${ }^{173}$ and 700 million acres of subsurface mineral estate, located primarily in the American West. ${ }^{174}$ It manages BLM's mineral estate as well as the mineral estate for the U.S. Forest Service, ${ }^{175}$ other Federal agencies, and it provides technical assistance involving about 56 million acres of Indian mineral estates. ${ }^{176} \mathrm{It}$ administers about 23,770 producing oil and gas leases involving about 100,000 wells, that in 2015 , produced $11 \%$ of the natural gas and $7 \%$ of the oil used in the U.S. ${ }^{177}$ Interior's Office of Natural Resources Revenue (ONRR) is authorized to

166. Fine Particulate Matter National Ambient Air Quality Standards: State Implementation Requirements, 81 Fed. Reg. 58,010, 58,018-19 (Aug. 24, 2016) (codified at 40 C.F.R. pts. 50, 51 \& 93).

167. See 42 U.S.C. § 7511a (2012).

168. See id.

169. Control Techniques Guideline Document; VOC Equipment Leaks From Natural Gas/Gasoline Processing, 49 Fed. Reg. 4432 (Feb. 6, 1984).

170. U.S. Envtl. Prot. Agency, ePA-453/B-16-001, Control TeChniques Guidelines for the OIL AND NATURAL GAS INDUSTRY, 3-7 to 3-8 tbl.3-1 (Oct. 2016), https://www.epa.gov/sites/production/files/201610/documents/2016-ctg-oil-and-gas.pdf.

171. Id. at 4-9.

172. U.S. Pub. LandS Conservation, Bureau of Land Management 70th Anniversary: America's Public Land Opportunity, PEW CHARITABLE TR. (July 15, 2016), http://www.pewtrusts.org/en/research-andanalysis/analysis/2016/07/15/bureau-of-land-management-70th-anniversary-americas-public-landopportunity.

173. BUREAU LAND MGMT., Facts, Subsurface Acreage Managed by the BLM, BLM.GOV, https://www.blm.gov/nhp/facts/acres.htm (last updated June 15, 2011) [hereinafter BLM Facts].

174. Bureau LAND MGMt., about the BLM Oil and Gas Program, U.S. Dep'T INTERIOR, https://www.blm.gov/programs/energy-and-minerals/oil-and-gas/about (last visited Dec. 13, 2017) [hereinafter About the BLM Oil and Gas Program].

175. See 30 U.S.C. § 226 (2012) (Leasing minerals on Forest Service land also involves the Federal Onshore Oil and Gas Reform Act of 1987 (FOOGLRA)).

176. BLM Facts, supra note 173.

177. About the BLM Oil and Gas Program, supra note 174. 
collect royalties on oil and gas produced on federal lands. ${ }^{178}$ In fiscal year 2015, it collected nearly $\$ 2.2$ billion. ${ }^{179} 48 \%$ of the $12.5 \%$ royalty is paid to the states. ${ }^{180}$ The payments to the states are expected to be used to help rural counties and local governments that have a reduced tax base because of the federal public lands within their borders. ${ }^{181}$ In Utah, the money is placed in the Permanent Community Impact Fund that is overseen by an 11-member Community Impact Board. ${ }^{182}$ Recently, the Board has been criticized for the fees paid to lawyers and engineering firms and for the grants of money that are used primarily to benefit the oil and gas industry. ${ }^{183}$

The BLM's legal authority concerning oil and gas resources is based on the Mineral Leasing Act of 1920, as amended, ${ }^{184}$ the Mineral Leasing Act of $1947,{ }^{185}$ the Naval Petroleum Reserves Production Act of 1976 (Alaskan leases), ${ }^{186}$ and the Federal Land Policy and Management Act of 1976 (FLPMA). ${ }^{187}$ The Mineral Leasing Act of 1920 (MLA) requires lessees to "use all reasonable precautions to prevent waste of oil or gas developed in the land," 188 and that leases include "a provision that such rules ... for the prevention of undue waste as may be prescribed by [the] Secretary shall be observed." 189 The BLM's regulations are found in 43 C.F.R. parts 3000 and $3100 .{ }^{190}$ For oil and gas operations where the surface is under the control of federal agencies other than the BLM, approval of the federal land manager (FLM) is required prior to an oil and natural gas owner/operator beginning construction. ${ }^{191}$

Generally, oil and gas leasing begins with the BLM's resource management plan (RMP), which governs the use of the land. ${ }^{192}$ FLPMA establishes requirements for land use planning on federal public land. It requires that the BLM "develop, maintain, and, when appropriate, revise land use plans" 193 to ensure that land management is conducted "on the basis of multiple use and sustained yield . . .."194

\footnotetext{
178. See 30 U.S.C. §§ 223-26 (2012).

179. GAO, supra note 72 , at 1 .

180. Richard Anklam \& Deborah Seligman, Oil and Natural Gas Taxing in New Mexico, N.M. STATE LEGISLATURE

https://www.nmlegis.gov/lcs/handouts/Oil\%20and\%20Natural\%20Gas\%20Taxing\%20in\%20New\%20Mexi co.pdf (last visited Jan. 9, 2018).

181. See Brian Maffly, Is Seven-County Coalition Squandering Money Earmarked for Rural Utah?, SALT LAKE TRIB., July 11, 2017, http://www.sltrib.com/news/environment/2017/07/11/is-seven-countycoalition-squandering-money-earmarked-for-rural-utah/.

182. Id.

183. Id.

184. 30 U.S.C. $\S \S 181-241$ (2012).

185. 30 U.S.C. §§ 351-359 (2012).

186. Naval Petroleum Reserves Production Act of 1976, Pub. L. No. 94-258, 90 Stat. 303 (current version at 42 U.S.C. §§ 6501-6508 (2012); 10 U.S.C § 7420; and amended 10 U.S.C. §§ 7421, 7436, 7438 (2012)).

187. Federal Land Policy and Management Act of 1976, Pub. L. No. 94-579, 90 Stat. 2743 (current version 43 U.S.C. §§ 1701-1787).

188. 30 U.S.C. $\S 225$ (2012).

189. $\S 187$.

190. 43 C.F.R. pts. 3000-3100 (2017).

191. See 43 C.F.R. § 3101.7-1 (2017).

192. 43 C.F.R. $\S 1601.0-5$ (2017)

193. 43 U.S.C. § 1712(a) (2012).

194. §1701(a)(7).
} 
The process for developing, maintaining, and revising RMPs is controlled by federal regulations. ${ }^{195}$ Under FLPMA, if the BLM wishes to change an RMP, it can only do so by formally amending the plan. ${ }^{196}$ There may also be a master leasing plan for areas with special resource conflicts that need to be protected. ${ }^{197}$ On December 12, 2016, the BLM amended its regulations dealing with planning under FLPMA. ${ }^{198}$ However, on March 27, 2017, President Trump signed Joint Resolution 44 to rescind this BLM planning rule, which will make it easier to obtain approval of oil and gas leases. ${ }^{199}$

The RMP requires a National Environmental Policy Act (NEPA) review. ${ }^{200}$ Under this review process, the BLM is typically responsible for an environmental review prior to authorizing oil and gas leases. ${ }^{201}$ On Indian lands, the Bureau of Indian Affairs (BIA) is also involved as it "authorizes surface activities (i.e., preparing the site for well-drilling activities and operating equipment for the production of oil and/or natural gas)." 202 The BLM and the BIA often enter into agreements designating one agency to take the lead in the NEPA process regarding the potential impacts of subsurface and surface activities. ${ }^{203}$ For significant projects, a full environmental impact statement (EIS) may be required. ${ }^{204}$ Among the important issues to be assessed are the cumulative impacts of the project and the alternatives to the project. ${ }^{205}$

On August 2, 2016, the White House Council on Environmental Quality (CEQ) released final guidance on considering climate change in environmental reviews. ${ }^{206}$ This guidance affects the federal land management agencies. ${ }^{207}$ On December 12 , 2016, the BLM amended its regulations on the preparation of land use plans as required by the FLPMA to include direct and indirect GHG emissions analysis. ${ }^{208}$ The

195. 43 C.F.R. $\S \S 1601.0-1610.9$ (2017).

196. $\S 1610.6-6$.

197. Kimberly Hirai, It's all in the master plan, HIGH COUNTRY NEWS, March 5, 2012, at 8. pt. 1600).

198. Resource Management Planning, 81 Fed. Reg. 89,580 (Dec. 12, 2016) (codified at 43 C.F.R.

199. Alan Kovski, Trump Signs Rollback of Interior's Federal Land Planning Rule, ENERGY \& CLIMATE Rep. (BNA), Mar. 27, 2017, BLoOMBERg LAW, ECR Issue No. 57.

200. 42 U.S.C. $\S \S 4321-4347$ (2012); see also 43 C.F.R. pt. 1600.

201. See generally John Ruple \& Mark Capone, NEPA, FLPMA, and Impact Reduction: An Empirical Assessment of BLM Resource Management Planning and NEPA in the Mountain West, 46 ENVTL. L. 953 (2016).

202. Review of New Sources and Modifications in Indian Country: Federal Implementation Plan for Managing Air Emissions from True Minor Sources Engaged in Oil and Natural Gas Production in Indian Country, 80 Fed. Reg. 56,554, 56,566 (Sept. 18, 2015) (to be codified at 40 C.F.R. pt. 49).

203. Id. 46 (2017)

204. The Department of the Interior's NEPA implementation regulations are found at 43 C.F.R. pt.

205. 40 C.F.R. $\S \S 1502.14,1508.7$.

206. Fact Sheet: White House Council on Environmental Quality Releases Final Guidance on Considering Climate Change in Environmental Reviews, WHITE HOuSE (Aug. 2, 2016), https://obamawhitehouse.archives.gov/the-press-office/2016/08/02/fact-sheet-white-house-councilenvironmental-quality-releases-final.

207. Dean Scott, Transportation, Energy Projects to Get Climate Reviews, ENv'T REP. (BNA), Aug. 5, 2016, BLOOMBERG LAW, ENR Issue No. 32. pt. 1600).

208. Resource Planning Management, 81 Fed. Reg. 89,580 (Dec. 12, 2016) (codified at 43 C.F.R. 
guidance involves the need to consider both the effect of the proposed action on climate change and the effect of climate change on the proposed action. ${ }^{209}$ The BLM responded on January 12, 2017, with its view of the CEQ's guidance. ${ }^{210}$ However, the Trump Administration withdrew the CEQ's guidance document for further consideration on April 5, 2017. ${ }^{211}$ The repeal of the guidance, "along with its directive not to use the social cost of carbon [as a] tool," leaves the approach to dealing with climate change issues in the NEPA process to each agency. ${ }^{212}$ The NEPA process begins with the development of an RMP, but after a lease is granted, a sitespecific scrutiny of the proposed oil or gas project is required. ${ }^{213}$

The BLM's oil and gas leasing process also triggers the need to comply with the Endangered Species Act (ESA). ${ }^{214}$ This begins with the development of an RMP and continues through the permit stage. ${ }^{215}$ The most important ESA provision is section 7, which requires federal agencies to consult with the U.S. Fish and Wildlife Service to ensure that any actions they undertake or authorize do not jeopardize threatened or endangered species. ${ }^{216}$ Compliance with the ESA involves the U.S. Fish and Wildlife Service field offices assessing the impacts to threatened and endangered species and critical habitats, which results in measures implemented to protect those resources that are incorporated in the FLMs' authorization. ${ }^{217}$ Only a small fraction of the oil and gas projects are reviewed under section 7, and when reviewed the process usually is relatively quick. ${ }^{218}$ The BLM expedites oil and gas leasing by using "programmatic biological opinions (PBiOps) to cover multiple similar actions." ${ }^{219}$ BLM has promulgated an Oil and Gas PBiOp on July 1, 1996, updated on September 28, 2001, that deals with small-scale oil and gas projects. ${ }^{220}$

209. Nicholas C. Yost, NEPA and Climate Change: Practitioners Should Take Note of CEQ's New Guidance, 45 ENVTL. L. ReP. NeWS \& ANALYSIS 10646, 10647 (2015).

210. BuREAU LAND MGMT., The Council on Environmental Quality Guidance on Consideration of Greenhouse Gas Emissions and the Effect of Climate Change in National

Environmental Policy Act Reviews, U.S. DEP'T INTERIOR, (Jan. 12, 2017), https://web.archive.org/web/20170515020934/https:/www.blm.gov/policy/pim-2017-003-0.

211. Withdrawal of Final Guidance for Federal Departments and Agencies on Consideration of Greenhouse Gas Emissions and the Effects of Climate Change in National Environmental Policy Act Reviews, 82 Fed. Reg. 16,576-01 (Apr. 5, 2017); see also Dawn Reeves, Trump Faces Murky Process to Revoke NEPA Climate Guide, Source Says, CLEAN AIR REP., Mar. 13, 2017, 2017 WLNR 8873555.

212. Dawn Reeves, Trump's Repeal of NEPA GHG Guide Leaves Agencies 'On Their Own', CLEAN AIR REP., May 18, 2017, 2017 WLNR 15287719.

213. See generally Resource Planning Management, 81 Fed. Reg. 89,580 (Dec. 12, 2016) (codified at 43 C.F.R. pt. 1600).

214. 16 U.S.C. $\S \S 1531-1544$ (2012).

215. Melinda Taylor et al., Protecting Species or Hindering Energy Development? How the Endangered Species Act Impacts Energy Projects on Western Public Lands, 46 ENVTL. L. REP. NEWS \& ANALYSIS 10924, 10928 (2016).

216. §1536(a)(2).

217. Review of New Sources and Modifications in Indian Country: Federal Implementation Plan for Managing Air Emissions from True Minor Sources Engaged in Oil and Natural Gas Production in Indian Country, 80 Fed. Reg. 56,554, 56,566 (Sept. 18, 2015) (to be codified at 40 C.F.R. pt. 49).

218. Taylor et al., supra note 215, at 10924.

219. Id.

220. Id. at 10927. 
The ESA is a controversial statute, and Congress regularly seeks to reduce the scope of the ESA. ${ }^{221}$

Another statute that may impact oil and gas projects is the National Historic Preservation Act (NHPA), which requires the impact on historic property to be evaluated by State and/or Tribal Historic Preservation Offices, ${ }^{222}$ and then appropriate measures to protect historic property must be taken by federal land managers. ${ }^{223}$

A permit to drill (APD) is normally a prerequisite to begin operations. ${ }^{224} \mathrm{~A}$ new well may not be drilled unless the operator first receives specific approval of its drilling plan through the submission of an application for an APD to the BLM. ${ }^{225}$ The permitting process will include a more detailed NEPA review. ${ }^{226}$ As part of the APD approval process, the BLM reviews the planned drilling activity and prepares an environmental assessment of the environmental impacts of the proposed drilling, after which the agency may approve the APD as submitted, approve it with appropriate modifications or conditions, or deny it. 227 In preparing this environmental assessment, the agency may incorporate by reference the general but more comprehensive environmental analysis included within its published RMP and focus the APD's environmental assessment on the issues specific to the project covered by the APD. ${ }^{228}$ Moreover, if the area has a state implementation plan, the CAA's general conformity provision requires the SIP to demonstrate that the proposed development will not cause or contribute to violations of the CAA or delay attainment of the NAAQS. ${ }^{229}$ On September 7, 2017, the Department of Interior issued Secretarial Order 3355 to streamline environmental reviews by imposing stringent time and page limits. The details are not yet provided, but the expectation is that these changes are designed to fast-track industrial development on BLM lands. ${ }^{230}$

The process of issuing APDs has been the subject of criticism because the BLM takes an average of 257 days to process them, which is well in excess of the laws

221. Id. at 10924.

222. 54 U.S.C. $\S \S 300101-305306$ (2012).

223. Review of New Sources and Modifications in Indian Country: Federal Implementation Plan for Managing Air Emissions from True Minor Sources Engaged in Oil and Natural Gas Production in Indian Country, 80 Fed. Reg. 56,554, 56,566 (Sept. 18, 2015) (to be codified at 40 C.F.R. pt. 49).

224. See 30 U.S.C. § 226 (2012).

225. § 226(p)(1)-(3); see also MarC Humphries, Cong. ReSearCh SeRV., R42432, U.S. CRUde OIL AND Natural Gas Production in Federal and Non-Federal Areas 7 (2016).

226. See generally Arnold W. Reitze, Jr., The Role of NEPA in Fossil Fuel Resource Development and Use in the Western United States, 39 B.C. EnVTL. AfF. L. ReV. 283 (2012).

227. Memorandum from U.S. Dep't of Interior, Bureau of Land Mgmt., Notice of Staking and Application for Permit to Drill Processing (Apr. 15, 2013).

228. 40 C.F.R. $\S 1502.20$ (2017).

229. 42 U.S.C. $\S 7506$ (c) (2012).

230. Brian Maffly, Federal Agency over Utah's Public Lands Quietly 'Streamlines' Its Environmental Reviews, SALT LAKE TRIB., Sept. 6, 2017 http://www.sltrib.com/news/business/2017/09/06/federal-agencyover-utahs-public-lands-quietly-streamlines-its-environmental-reviews/; see generally Elizabeth Shogren, Drilling Threatens Dinosaur National Monument, HIGH CoUnTRY NEWS, Aug. 7, 2017. 
30-day limit. ${ }^{231}$ The Vernal, Utah field office has the second-largest backlog of lease applications. ${ }^{232}$ However, as of September 2015, there were nearly 2,000 APDs issued by the Vernal office that were not being developed; there were more than 7,500 nationwide not being developed. ${ }^{233}$ In 2016, the BLM issued 2,184 drilling permits, but only 847 wells were being drilled on federal leases. ${ }^{234}$ BLM had 325 people working on permitting on the nation's public lands and 90 vacancies. ${ }^{235}$ The Secretary of the Interior wants the permitting process to be streamlined. ${ }^{236}$ To accomplish this, the Trump Administration's budget calls for $\$ 16$ million to expedite the APD leasing process. ${ }^{237}$

On November 18, 2016, the BLM promulgated its Waste Prevention Rule that imposes various requirements on oil and gas producers working on federal lands. ${ }^{238}$ The Rule aims to reduce waste and prevent the release of methane into the atmosphere. ${ }^{239}$ It prohibits venting of natural gas with few exceptions, including emergency venting, requires producers to reduce wasteful flaring of gas by capturing for sale, and requires producers to use an instrument approach to leak detection in order to reduce gas leaks throughout oil and gas production. ${ }^{240}$

The Waste Rule was challenged by the States of Wyoming, Montana, North Dakota, the Western Energy Alliance and the Independent Petroleum Association of America that were seeking a preliminary injunction to enjoin the rule from taking effect, but the Petitioners motion was rejected. ${ }^{241}$ However, the case continues. ${ }^{242}$

\section{A. Royalties}

BLM-administered leases "shall be conditioned upon the payment of a royalty at a rate of not less than 12.5 percent in amount or value of the production removed or sold from the lease." 243 The waste regulation promulgated on November 18, 2016, allows the BLM, after the effective date of the rule, to set rates at or above $12.5 \% .{ }^{244}$ However, under the Trump Administration, the oil and gas industry can

231. Brian Maffly, Interior Secretary Ryan Zinke Orders Faster Approval of Oil and Gas Drilling on Federal Lands, SALT LAKE TRIB., July 7, 2017, http://www.sltrib.com/news/environment/2017/07/07/interiorsecretary-ryan-zinke-orders-faster-approval-of-oil-and-gas-drilling-on-federal-lands/ [hereinafter Interior Secretary Ryan Zinke]

232. Id.

233. Id.

234. Id.

235. Alan Kovski, Interior to Step Up Pace of Oil, Gas Leasing on Federal Land, Dally EnV'T ReP. (BNA), June 30, 2017, BLOOMBERG LAW, DEN Issue. No. 125.

236. Alan Kovski, Interior's Zinke Wants Oil and Gas Permitting Streamlined, Energy \& Climate ReP. (BNA), July 6, 2017, BLOOMBERG LAW, ECR Issue No. 129.

237. Interior Secretary Ryan Zinke, supra note 231.

238. Waste Prevention, Production Subject to Royalties, and Resource Conservation, 81 Fed. Reg. $83,008,83013$ (Nov. 18, 2016) (codified at 43 C.F.R. pts. 3100, 3160, \& 3170).

239. 30 U.S.C. § 225 (2012); see generally 43 C.F.R. § 3179.6 (2017).

240. 30 U.S.C. § $225 ; 43$ C.F.R. § $3179.6($ b)(1)-(7).

241. See generally Wyoming v. U.S. Dep't. of the Interior, No. 2:16-CV-0285-SWS, 2017 WL 161428 (D. Wyo. Jan. 16, 2017).

242. See infra Section III.H.

243. 30 U.S.C. § $226(\mathrm{~b})(1)(\mathrm{A})$.

244. Waste Prevention, Production Subject to Royalties, and Resource Conservation, 81 Fed. Reg. $83,008,83013$ (Nov. 18, 2016) (codified at 43 C.F.R. pts. 3100, 3160, \& 3170). 
be expected to avoid additional costs. On April 4, 2017, the Office of Natural Resources of the Department of Interior proposed to repeal the Consolidated Federal Oil \& Gas and Federal Indian Coal Valuation Reform Rule, which would keep the preexisting regulation in effect. ${ }^{245}$ The repeal of the rule would cost the federal government an estimated $\$ 78$ million in lost royalties. ${ }^{246}$

Oil and gas operators on federal lands are required to submit monthly Oil and Gas Operations Reports (OGOR), which account for the oil and gas produced. ${ }^{247}$ Most natural gas that is produced is sold and royalties are paid, but gas that is leaked, vented, burned, or used to operate equipment at the production site is usually not subject to royalty payments unless the BLM considers the gas to be improperly released. ${ }^{248}$ Flaring, discussed infra Section III(B), has increased rapidly in recent years because oil and gas development frequently occurs in remote locations where transport is not available for the natural gas that is also produced as part of an oil operation. ${ }^{249}$ EPA estimates that in 2008 , approximately $\$ 58$ million in federal royalty payments were avoided as a result of the venting and flaring exemption. ${ }^{250}$ Venting, flaring, and on-site use that is generally royalty free is the subject of BLM guidance known as Notice to Lessees and Operators of Onshore Federal and Indian Oil and Gas Leases (NTL-4a) issued in 1979. ${ }^{251}$

The rule updates the pre-existing royalty provisions to "specifically define when a loss of gas is considered 'unavoidable' and royalty-free, and when it is considered 'avoidable' and subject to royalties." ${ }^{252}$ A natural gas loss is unavoidable if the "operator has complied with all applicable requirements and taken prudent and reasonable steps to avoid waste ...." ${ }^{253} \mathrm{~A}$ loss is also "unavoidable when gas is flared from a well that is not connected to a gas pipeline" and the BLM has not determined "that the loss of gas is avoidable.".254 "All other losses of gas . . are deemed avoidable and subject to royalties." ${ }^{255}$ Avoidable losses include releases due to operator negligence, failure to take reasonable measures to control the loss, or a failure of the operator to comply with the lease. ${ }^{256}$ The BLM's guidance has been criticized by the Government Accountability Office for not providing clear and

245. See generally Repeal of Consolidated Federal Oil \& Gas and Federal \& Indian Coal Valuation Reform, 82 Fed. Reg. 16,323 (proposed Apr. 4, 2017) (codified at 30 C.F.R. pts. 1202 \& 1206) (voiding the rule concerning royalties published at $81 \mathrm{Fed}$. Reg. 43,338 (July 1, 2017)).

246. Jennifer A. Dlouhy, Interior Proposes to Scrap Obama Rule for Coal, Oil Royalties, ENERGY \& Climate Rep. (BNA), Apr. 4, 2017, BLoomberg LAW, ECR Issue No. 63.

247. GAO, supra note 72 , at 2 .

248. Id. at 4,18 .

249. Id. at 2 .

250. Id. at 3 .

251. Royalty or Compensation for Oil and Gas Lost; Revocation of Certain Provisions Contained in Notices to Lessees and Operators (NTL-4), 44 Fed. Reg. 76,600-01 (Dec. 27, 1979).

252. Waste Prevention, Production Subject to Royalties, and Resource Conservation, 81 Fed. Reg. $83,008,83,013$ (Nov. 18, 2016).

253. Id.

254. Id.

255. Id.

256. GAO, supra note 72 , at 9 . 
consistent guidance. ${ }^{257}$ Moreover, BLM officials approve many venting or flaring requests that do not comply with the existing guidance. ${ }^{258}$

\section{B. Waste, Venting and Flaring}

On January 22, 2016, BLM announced its proposed methane and waste reduction regulation that would update the guidance on venting, flaring, and controlling equipment leaks. ${ }^{259}$ Venting results in methane being released into the atmosphere with its much higher GHG impact; flaring combusts natural gas and produces carbon dioxide as well as conventional air pollutants. ${ }^{260}$

The BLM's Waste Prevention final rule, issued on November 18, 2016, aims to reduce the waste of natural gas from operations based on mineral leases administered by the bureau. ${ }^{261}$ While oil and gas production technology has advanced dramatically in recent years, the BLM's rules to minimize waste of gas have not been updated in over 30 years, although the technology used in the oil and gas industry has changed dramatically. Over the past decade, the United States has experienced a dramatic increase in oil and natural gas production, but BLM states "the American public has not benefited from the full potential of this energy resource, due to venting, flaring and leaks of significant quantities of gas during the production process." 262 "Federal and Indian onshore lessees and operators reported to the Office of Natural Resources Revenue (ONRR) that they vented or flared 462 billion cubic feet (Bcf) of natural gas between 2009 and 2015-enough gas to serve about 6.2 million households for a year, assuming 2009 usage levels." 263 In 2015, operators increased the use of flaring with most of the releases being routine flaring of associated gas from development oil wells. ${ }^{264}$ More than $88 \%$ of the "flaring occurred in North Dakota, South Dakota, and New Mexico." 265 If the oil and gas industry had to pay royalties based on all the gas they extract rather than the gas they transport to market, it would have an incentive to minimize waste. Such an approach would allow regulations to be simplified because market forces would encourage conservation of the resource.

The 2016 Waste Prevention rule "amends the BLM's oil and gas regulations at 43 CFR part 3160 to include requirements for a waste minimization plan . ..."266 It "adds new subparts 3178 and 3179 to 43 CFR part 3170 [to] address royalty-free

257. Id. at $12,27$.

258. Id. at 18.

259. Waste Prevention, Production Subject to Royalties, and Resource Conservation, 81 Fed. Reg. 6616 (Feb. 8, 2016) (codified at 43 C.F.R. pts. 3100, 3160, \& 3170).

260. GAO, supra note 72 , at 6 .

261. Waste Prevention, Production Subject to Royalties, and Resource Conservation, 81 Fed. Reg. 83,008 (Nov. 18, 2016) (codified at 43 C.F.R. pts. 3100, 3160, \& 3170).

262. Kimberly Brubeck, Interior Department Announces Final Rule to Reduce Methane Emissions \& Wasted Gas on Public, Tribal Lands, U.S. DEP'T INTERIOR (Nov. 15, 2016), https://www.doi.gov/pressreleases/interior-department-announces-final-rule-reduce-methaneemissions-wasted-gas-public.

263. Waste Prevention, Production Subject to Royalties, and Resource Conservation, 81 Fed. Reg. at 83,009 .

264. Id. at 83,011

265. Id.

266. Id. at 83,009 . 
use of lease production (subpart 3178) and waste prevention through reduction of venting, flaring and leaks (subpart 3179)." 267 The BLM has considered and minimized potential overlaps with other federal, state, or tribal regulations because "overlapping regulatory regimes can create difficulties for operators . . ." ${ }^{268}$ In addition, this rule authorizes the BLM to grant variances from particular requirements if a State or tribe demonstrates it imposes equally effective requirements. ${ }^{269}$

The Waste Prevention Rule is considered by BLM to be a necessary step to minimize waste of the public's natural gas resources. ${ }^{270}$ Neither EPA nor the states have adequately addressed "the issue of waste of gas from BLM-administered leases." ${ }^{271}$ The EPA's regulations focus on air pollution, not waste prevention. ${ }^{272}$ "[T]hey cover only new, modified and reconstructed sources; and they do not address wasteful routine flaring of associated gas from oil wells . . . ."273 No State has established a comprehensive set of requirements addressing "venting, flaring and leaks-and only a few States have significant requirements in even one of these areas." $^{274}$

The Waste Prevention Rule focuses on venting and flaring of associated gas from oil wells, gas leaks from equipment, "operation of high-bleed pneumatic controllers and certain pneumatic pumps, gas emissions from storage vessels, downhole well maintenance and liquids unloading, and well drilling and completions." 275 This rule requires operators to reduce waste of gas. ${ }^{276}$ It establishes clear criteria for when flared gas will qualify as waste and be subject to royalties, and which on-site uses of natural gas are exempt from royalties. ${ }^{277}$

$[B]$ eginning one year from the effective date of the final rule, operators must capture 85 percent of their adjusted total volume of gas produced each month. This percentage increases to 90 percent in 2020, 95 percent in 2023, and 98 percent in 2026. An operator's adjusted total volume of gas produced is calculated based on the quantity of high pressure gas produced from the operator's development oil wells that are in production, adjusted to exempt a specified volume of gas per well, which declines over time. Beginning one year from the effective date of the final rule, operators are allowed to exempt 5,400 Mcf gas per well per month,

\footnotetext{
267. Id.

268. Id. at 83,010.

269. Waste Prevention, Production Subject to Royalties, and Resource Conservation, 81 Fed. Reg. at 83,010 .

270. Id.

271. Id. at 83,010 .

272. Id.

273. $I d$.

274. Id.

275. Waste Prevention, Production Subject to Royalties, and Resource Conservation, 81 Fed. Reg. at 83,010

276. $I d$.

277. Id.
} 
and this quantity declines to 3,600 beginning in $2019,1,800$ in $2020,1,500$ in 2021, 1,200 in 2022, 900 in 2024, and 750 from 2025 on. ${ }^{278}$

It might be worth noting that at even the current depressed price of natural gas at about \$2.86 Mcf in July 2017, the oil and gas industry is allowed to avoid royalties on natural gas valued at over $\$ 15,000$ per month, per well. ${ }^{279}$

Operators have "the option to meet their capture targets on a lease-by-lease basis, or an average basis over all of their Federal or Indian production from development oil wells county-by-county or State-by-State," which enhances flexibility and makes the targets less costly to meet. ${ }^{280}$ The flaring rule when fully implemented is expected to reduce methane releases up to $49 \%$ relative to 2015 levels. ${ }^{281}$

The rule also "requires operators to submit a Waste Minimization Plan when they apply for a permit to drill a new development oil well." 282 "While the provisions of a plan [are] not enforceable against the operator, plan submission is mandatory, and the plan must include specific elements [that are] listed in the regulations." 283 "[F]ailure to submit a complete and adequate plan could be grounds for denial of an application for a permit to drill (APD)."284

The Waste Prevention rule is under attack by the Republican-led Congress, which is discussed infra Section III(I).

\section{Leaks}

The BLM considers leaks to be "the second largest source of vented gas from Federal and Indian leases ...." 285 "Leak Detection and Repair (LDAR) programs are [considered to be] a cost-effective means of reducing waste in oil and gas production, and ... once leaks are detected, the vast majority can be repaired with a positive return to the operator." 286 "The final rule requires operators to use an instrument-based approach to leak detection." 287 "[O]perators [may] use optical gas imaging equipment, portable analyzers deployed according to the protocol prescribed in [the] EPA's Method 21, or an alternative leak detection device approved by the BLM." ${ }^{288}$ Operators are required to repair leaks "within 30 days of discovery, absent good cause, and verify that the leak is fixed." 289 "[R]ecords

278. Id. at 83,011.

279. Natural Gas: End of day Commodity Futures Price Quotes for Natural Gas (NYMEX), NASDAQ, http://www.nasdaq.com/markets/natural-gas.aspx (last visited Jan. 9, 2018).

280. Waste Prevention, Production Subject to Royalties, and Resource Conservation, 81 Fed. Reg. at 83,011 .

281. Id.

282. Id.

283. Id.

284. Id.

285. Id.

286. Waste Prevention, Production Subject to Royalties, and Resource Conservation, 81 Fed. Reg. at 83,011 .

287. Id. at 83,027 .

288. Id. at 83,011 (footnote omitted).

289. Id. 
documenting the dates and results of leak inspections, repairs, and follow-up inspections" must be kept. ${ }^{290}$

On December 8, 2017, following a thirty-day public comment period, the BLM finalized delays of the Waste Prevention Rule, which is the portion of the methane rule intended to minimize venting, flaring, and leaking. ${ }^{291}$ This action drew new lawsuits filed on December 19th by the States of California and New Mexico, and a coalition of environmental groups. ${ }^{292}$ The plaintiffs contend that the Trump Administration has violated the Mineral Leasing Act of 1920 requiring the prevention of natural resources waste. ${ }^{293}$ Also, the plaintiffs allege the Administration has again violated the Administrative Procedures Act as well as procedural requirements in the National Environmental Policy Act. ${ }^{294}$ In the final rule, the BLM explained that the compliance delays were necessary to give the agency time to propose a replacement rule. ${ }^{295}$

\section{Pneumatic Controllers and Pumps}

The BLM estimates that in 2014 its lessees "lost about 14.9 Bcf of natural gas from pneumatic controllers and about 2.3 Bcf from pneumatic pumps." ${ }^{296}$ The final rule requires the replacement of "high-bleed pneumatic controllers with low-bleed or no-bleed pneumatic controllers within one year of the effective date of the final rule." 297 This requirement is based on the "requirements in Colorado and Wyoming (in part of the State), and it applies only to pneumatic controllers that are not covered by EPA regulations." 298

Operators must "replace pneumatic diaphragm pumps that operate 90 or more days per year with zero-emissions pumps, or route the pump exhaust gas to processing equipment." 299 If "routing the exhaust gas to processing equipment would be technically infeasible or unduly costly, the operator must route the pneumatic diaphragm pump to a combustor or flare, if one is located on the site." 300 "[T]he final rule does not apply to pneumatic pumps that are subject to EPA regulations." ${ }^{301}$ Moreover, "an exemption from the requirements for pneumatic controllers or pumps [is available] if the operator demonstrates and the BLM [agrees] that replacing the pneumatic pump(s) would impose ... costs [that would]

290. Id.

291. Alan Kovski, Delays on Natural Gas Emission Controls Draw Lawsuits, DAILY REP. EXECUTIVES (BNA), Dec. 20, 2017.

292. Id.

293. Id.

294. Id.

295. Id.

296. Id. at 83,012 .

297. Waste Prevention, Production Subject to Royalties, and Resource Conservation, 81 Fed. Reg. at 83,012 .

298. Id.

299. Id.

300. Id.

301. Id. 
cause the operator to [end] production and abandon significant recoverable oil reserves...."302

\section{E. Storage Vessels}

The BLM estimates "that 2.94 Bcf of natural gas was lost in 2014 from storage tank venting on Federal and Indian lands." ${ }^{303}$ Of that volume, about half was released from oil operations and half from natural gas operations. ${ }^{304}$ To control vapor releases will require either the installation of a vapor recovery unit (VRU) or the routing of the vapors to a flare or combustor. ${ }^{305}$ "New, modified and reconstructed vessels used in oil and gas production are already subject to EPA [requirements]" that mandate "at least a 95 percent reduction in VOC emissions from baseline levels." 306 "Colorado and part of Wyoming have similar, somewhat more stringent requirements for storage vessels." ${ }^{307}$ Operators may "request an exemption from these requirements if the operator demonstrates, and the BLM [agrees], that [compliance] ... would impose ... costs [that] cause the operator to cease production and abandon significant recoverable oil reserves under the lease." 308

\section{F. Drilling, Completion, and Related Operations}

"The EPA requires new hydraulically fractured and refractured oil or gas wells to capture or flare gas that ... . would be released during drilling and completion operations." 309 The BLM also requires that waste of gas releases during these operations be minimized "by requiring operators to capture, use, flare, or inject the gas." 310 Complying with the EPA's requirements should meet the BLM requirements. ${ }^{311}$

\section{G. Summary of Costs and Benefits}

"[T]he BLM estimates that the benefits of this rule would outweigh its costs by a significant margin." 312 "The BLM estimates this rule will pose costs ranging from \$114-\$279 million per year (using a 7 percent discount rate to annualize capital costs) or $\$ 110-\$ 275$ million per year (using a 3 percent discount rate to annualize capital costs) over the next 10 years." 313 "The engineering compliance costs

302. Id.

303. Waste Prevention, Production Subject to Royalties, and Resource Conservation, 81 Fed. Reg. at 83,012 .

304. Id.

305. Id.

306. Id.

307. Id.

308. Id. at 83,012 .

309. Waste Prevention, Production Subject to Royalties, and Resource Conservation, 81 Fed. Reg.

310. Id. at $83,012-13$.

311. Id. at 83,013 .

312. Id.

313. Id. 
presented do not include potential cost savings from the recovery and sale of natural gas ...." 1314

In its Regulatory Impact Analysis (RIA), the BLM estimated "that average costs for a representative small operator would increase by about $\$ 55,200$, which would result in an average reduction in profit margin of 0.15 percent . . ." ${ }^{\prime 315}$ The BLM estimates that the final rule would "reduce methane emissions by [roughly] 35\% from the 2014 estimates . . ." ${ }^{\prime 316}$ The BLM estimates "this final rule will produce additional royalties of $\$ 3-\$ 10$ million per year (discounted at 7 percent) or $\$ 3-\$ 14$ million per year (discounted at 3 percent)." ${ }^{117}$

\section{H. Congressional Action}

On February 3, 2017, the House passed House Joint Resolution 36 to rescind the BLM's November 2016 methane venting and flaring rule. ${ }^{318}$ The Senate version, S.J. Res. 11, was rejected on May 10, 2017 in a forty-nine to fifty-one vote in which three Republican members voted not to kill the Interior's rule. ${ }^{319}$ The vote is considered a defeat for the fossil-fuel industry and for groups linked to the Koch Brothers, but the defeat may be short-lived. ${ }^{320}$ The Senate vote was influenced by the expectation that the Department of the Interior will issue a new revised methane rule. ${ }^{321}$ "In June [2017], the Interior Department suspended compliance with those parts of the rule that was not already in effect ...." ${ }^{322}$ This led to another lawsuit on July 5, 2017, filed by the State of California and New Mexico, challenging the BLM's effort to postpone the Waste Prevention Rule. ${ }^{323}$ California and New Mexico claim that the BLM lacks authority under Section 705 of the Administrative Procedure Act to postpone compliance dates after a rule has gone into effect. ${ }^{324}$ The U.S. District Court for the Northern District of California agreed with the plaintiffs' that postponing implementation of a rule already in effect violated APA notice and comment requirements. ${ }^{325}$ Furthermore, BLM's postponement decision

314. Id.

315. Waste Prevention, Production Subject to Royalties, and Resource Conservation, 81 Fed. Reg. at $83,013-14$.

316. Id. at 83,069 .

317. Id. at 83,014

318. H.R.J. Res. 36, 115th Cong. (2017).

319. Alan Kovski \& Rachel Leven, Methane Rule Under Fire at Interior After Surviving Senate, ENV'T REP. (BNA), May 10, 2017, BLOOMBERG LAW, ENR Issue No. 19; CRA Repeal Efforts End in Failure for GOP of BLM Methane Rule Vote, CLEAN AIR REP., May 18, 2017, 2017 WLNR 15287687.

320. Matthew Daly, GOP, Fossil-Fuel Industry Burned in Methane Vote, SALt LAKE TRIB., May 10, 2017, http://archive.sltrib.com/article. php?id=5275098\&itype=CMSID.

321. Kovski \& Leven, supra note 319.

322. Alan Kovski, Methane Hot Spot in West Troubles Regulators and Industry, DAILY ENV'T REP. (BNA), Aug. 4, 2017, BLOOMBERG LAW, DEN Issue No. 149.

323. Complaint for Declaratory and Injunctive Relief, California v. U.S. Bureau of Land Mgmt., No. 3:17-cv-03804-EDL, 2017 WL 2879910 (N.D. Cal. Oct. 4, 2017) (complaint filed on July 5, 2017); Carolyn Whetzel, Methane Leak Rule in Effect Can't Be Halted, Lawsuit Says, Energy \& Climate ReP. (BNA), July 5, 2017, BLOOMBERG LAW, ECR Issue No. 128.

324. Whetzel, supra note 323.

325. California v. U.S. Bureau of Land Mgmt., No. 3:17-3804, 2017 WL 4416409, at *9-10 (N.D. Cal. Oct. 4, 2017). 
was arbitrary and capricious because the agency only considered the costs of the rule and did not give any weight the rule's benefits, such as decreased resource waste, air pollution, and enhanced public revenues. ${ }^{326}$

\section{STATE REGULATION OF VOCS AND METHANE}

This section discusses the state laws to control the VOC and methane emissions of major oil and gas producing states located in the western United States: Utah, California, Colorado, New Mexico, and Wyoming. The 2014 production of natural gas in million cubic feet was 453,207 for Utah; 252,718 for California; 1,631,391 for Colorado; 1,180,808 for New Mexico; and 1,791,235 for Wyoming. ${ }^{327}$ Texas is the most important producer of natural gas with 7,953,343 million cubic feet. ${ }^{328}$ The states rank for natural gas production was Wyoming (6), Colorado (5), New Mexico (9), Utah (12), and California (15)..$^{329}$ The 2014 production of crude oil in thousand barrels was 40,905 for Utah; 204,269 for California; 95,192 for Colorado; 123,686 for New Mexico; and 76,078 for Wyoming. ${ }^{330}$ Texas is the most important producer of crude oil with $1,155,684,000$ barrels. ${ }^{331}$ North Dakota is second. ${ }^{332}$ The rankings for crude oil production are California (3), New Mexico (4), Colorado (7), Wyoming (8), and Utah (11). ${ }^{333}$ Colorado and Wyoming are considered to be states with stringent air pollution control requirements, while Utah and New Mexico are considered to be relatively lax. ${ }^{334}$ Utah, however, is developing new regulations to control VOC, and other air pollutants, from existing oil and gas operations, but they have not yet been approved. ${ }^{335}$ The proposed regulations were approved by the Utah Air Quality Board for public comment on September 6, 2017. Methane is not expected to be directly regulated, but it is indirectly regulated through VOC emission limits. ${ }^{336}$ This is discussed infra Section IV(A)(iv).

In March 2015, the BLM finalized its rule concerning hydraulic fracturing (fracking) on public lands, ${ }^{337}$ but the rule never went into effect. ${ }^{338}$ In a successful

326. James L. Simpson, State of California, et al. v. United States Bureau of Land Management, et al. A.B.A.: SEC. ENV'T., ENERGY, \& RESOURCES (Oct. 24, 2017), https://www.americanbar.org/groups/environment_energy_resources/committees/dch/aq/20171024_st ate_of_california_v_united_states_bureau_of_land_management.html.

327. U.S. ENERgy INFo. AdMin., State Energy Production Estimates 1960 Through 2014, at 1 tbl.P1 (2014) [hereinafter StATE ENERGY PROdUCtION 2014].

328. Id.

329. U.S. ENERGY INFO. ADMIN., Rankings: Natural Gas Marketed Production, 2016

(million cu fT.), EIA, https://www.eia.gov/state/rankings/\#/series/47 (last visited Jan. 9, 2018).

330. U.S. ENERGY INFO. ADMIN., supra note 327, at 1 tbl.P1.

331. Id.

332. Id.

333. U.S. Energy Info. Admin, Rankings: Crude Oil Production, July 2017 (thousand barrels), EIA, https://www.eia.gov/state/rankings/?sid=US\#/series/46 (last visited Jan. 9, 2018).

334. Milford, supra note 60, at 2-3.

335. Changes are proposed for Utah air regulations, UTAH ADMIN. CODE r. 307-150, -401, -504, -506 to -510 .

336. See infra Section IV(A)(iv).

337. Oil and Gas; Hydraulic Fracturing on Federal and Indian Lands, 80 Fed. Reg. 16,128 (Mar. 26, 2015).

338. Jack R. Luellen, Oil and Natural Gas Production: Opportunities, Challenges, and Political Quandaries, 30 NAT. RESOURCES \& ENv'T 15, 17 (2016). 
motion for a preliminary injunction brought by Wyoming, Colorado, Utah, North Dakota, the Ute Tribe, and industry groups, the U.S. District Court for the District of Wyoming blocked the implementation of the rule. ${ }^{339}$ The court held that the Energy Policy Act of 2005 limited the EPA's regulatory authority to hydraulic fracturing involving the use of diesel fuel. ${ }^{340}$ On June 21, 2016, the Wyoming Federal District Court held that the BLM lacked Congressional authority to promulgate the hydraulic fracturing rule. ${ }^{341}$ On March 15, 2017, the Trump administration announced it would begin rescinding the rule. ${ }^{342}$ This shifts much of the regulatory authority over fracking to the states. Similar efforts by the Trump Administration are being made to end environmental protection in general and to limit the regulation of the oil and gas industry. ${ }^{343}$ This is shifting the control of air pollution from the production and processing of oil and gas to the states.

The material that follows sketches the basic approach of five western states, and their regulation of air pollution, including methane emissions, from oil and gas production. It should be acknowledged that comparison of the state programs is difficult and can be misleading. While the applicable statutes and regulations can be analyzed, their implementation is more difficult to assess. The legal regimen for stationary sources of air pollution control is focused on major sources, but states usually treat most oil and gas emission sources as minor sources. This results in a lower level of attention being given to these sources. Moreover, minor sources are often regulated through individual permits. Such an approach gives substantial discretion to the state agency concerning what requirements to impose. Alternatively, general permits can be used to cover multiple oil and gas emission sources. Regardless of the stringency of a state's regulations, the level of enforcement can determine the effectiveness of the program. Most state air pollution enforcement efforts are woefully underfunded, ${ }^{344}$ which makes compliance largely dependent on the industry's willingness to meet emissions control requirements.

\section{A. Utah}

Utah has about 12,300 producing oil and gas wells. ${ }^{345}$ There were 8,583 producing natural gas wells in $2015 .{ }^{346}$ The major production of oil in 2016 was in

339. Wyoming v. U.S. Dep't of the Interior, 136 F. Supp. 3d 1317, 1354 (D. Wyo. 2015).

340. Lisa A. Decker, Overreach in Agency Rulemaking: Judicial Pushback?, 30 NAT. ResOURCES \& ENV'T 57, 57 (2016).

341. Wyoming v. U.S. Dep't of the Interior, No. 2:15-CV-041-SWS, 2016 WL 3509415, at *12 (D. Wyo. June 21, 2016).

342. Jennifer A. Dlouhy \& Thomas Korosec, Trump Administration to Rescind Obama's BLM Rule on Fracking, ENeRGY \& ClimATE ReP. (BNA)., Mar. 15, 2017, BLOOMBERG LAW, ECR Issue No. 49.

343. See infra Part VI.

344. Jie Jenny Zou, State Cutbacks, Recalcitrance Hinder Clean Air Act Enforcement, News \& OBSERVER (Oct. 13, 2016), http://www.newsobserver.com/news/politics-government/statepolitics/article107964782.html.

345. Utah Oil and Gas, UtAH Dep't NAt. Res, Div. OIL, GAS, \& Mining, https://oilgas.ogm.utah.gov/oilgasweb/facts/facts-5main.xhtml (last visited Jan. 9, 2018).

346. U.S. ENERGY INFO. AdMIN., Natural Gas: Number of Producing Gas Wells, EIA, https://www.eia.gov/dnav/ng/ng_prod_wells_s1_a.htm (last visited Jan. 9, 2018). 
Duchesne, Uintah, and San Juan counties; ${ }^{347}$ the major production of natural gas in 2016 was in Uintah, with Carbon and Duchesne counties in a distant second and third place. ${ }^{348}$ Utah has three of the top one-hundred gas fields in the U.S.: Natural Buttes, Chapita Wells, and Red Wash. ${ }^{349}$ It has three of the top one-hundred oil fields: Monument Butte, Altamont-Bluebell, and Greater Aneth. ${ }^{350}$ Utah is the state with the fourth highest number of mineral leases on federal lands. ${ }^{351}$

In Utah, approximately $90 \%$ of the active oil and gas wells are located in "Indian Country" where the state does not have regulatory authority over air emissions. ${ }^{352}$ However, only about one-fourth of Utah's crude oil production came from Indian lands in 2013. ${ }^{353}$ Regulation of oil and gas activities in Indian Country is the responsibility of EPA and the Indian tribes. ${ }^{354}$

Utah regulates air emissions from oil and gas operations based on its Administrative Code R307-501-1 to R307-501-4. ${ }^{355}$ The regulations apply to "natural gas exploration, product, and transmission operations; well production facilities; natural gas compressor stations; and natural gas processing plants . ..." 356 The regulations do not apply to oil refineries. ${ }^{357}$ The basic requirements are found in R307-501-4. General Provisions:

(1) General requirements for prevention of emissions and use of good air pollution control practices.

(a) All crude oil, condensate, and intermediate hydrocarbon liquids collection, storage, processing and handling operations, regardless of size, shall be designed, operated and maintained so as to minimize emission of volatile organic compounds to the atmosphere to the extent reasonably practicable.

(b) At all times, including periods of start-up, shutdown, and malfunction, the installation and air pollution control equipment shall be maintained and operated in a manner consistent with good air pollution control practices for minimizing emissions.

(c) Determination of whether or not acceptable operating and maintenance procedures are being used will be based on information available to the director, which may include, but is not limited to,

347. Utah Oil Production by County (past 5 years), UTAH DeP'T NAT. RES, DIV. OIL, GAS, \& MINING, https://oilgas.ogm.utah.gov/oilgasweb/statistics/oil-prod-by-cnty.xhtml (last updated Nov. 17, 2017).

348. Utah Gas Production by County (past 5 years), UtAH DeP'T NAT. ReS, DIV. OIL, GAS, \& MINING, https://oilgas.ogm.utah.gov/oilgasweb/statistics/gas-prod-by-cnty.xhtml (last updated Nov. 17, 2017).

349. Oil and Gas Facts, UtAH Dep'T NAT. RES, DIv. OIL, GAS, \& MinIng, https://oilgas.ogm.utah.gov/oilgasweb/facts/facts-main.xhtml (last updated Apr. 2015).

350. Id.

351. U.S. Energy INfo. AdMin., Utah State Profile and Energy Estimates, EIA, https://www.eia.gov/state/analysis.php?sid=UT (last updated Nov. 16, 2017).

352. Ozone in the Uinta Basin, UTAH DEP'T ENVTL. QUALITY, https://deq.utah.gov/locations/U/uintahbasin/ozone/overview.htm (last visited Jan. 9, 2018).

353. Oil and Gas Facts, supra note 349.

354. See generally Reitze, supra note 1.

355. UTAH ADMIN. CODE r. 307-501-1 to -4 (2017).

356. r. 307-501-3(1).

357. r. 307-501-3(2). 
monitoring results, infrared camera images, opacity observations, review of operating and maintenance procedures, and inspection of the source.

(2) General requirements for air pollution control equipment.

(a) All air pollution control equipment shall be operated and maintained pursuant to the manufacturing specifications or equivalent to the extent practicable and consistent with technological limitations and good engineering and maintenance practices.

(b) The owner or operator shall keep manufacturer specifications or equivalent on file.

(c) In addition, all such air pollution control equipment shall be adequately designed and sized to achieve the control efficiency rates established in rules or in approval orders issued under R307-401 and to handle reasonably foreseeable fluctuations in emissions of VOCs during normal operations. Fluctuations in emissions that occur when the separator dumps into the tank are reasonably foreseeable. ${ }^{358}$

Utah has jurisdiction over lands outside of Indian Country. It subjects emission sources to its New Source Review (NSR) requirements if they have emissions greater than five tons per year of any criteria pollutant or greater than 500 pounds per year of any single hazardous air pollutant or 2,000 pounds per year of all hazardous air pollutants. ${ }^{359}$ However, most oil and gas emission sources do not meet the threshold for NSR applicability. ${ }^{360}$

Utah's Division of Air Quality has issued sixty-six operating permits to major sources based on Title $V$ of the CAA. ${ }^{361}$ Only nine permits have been issued to oil and gas operations - one to a natural gas processing plant and eight to compressor stations. ${ }^{362}$ This means that nearly all the oil and natural gas facilities are regulated as minor sources, which are defined as sources that are not major. ${ }^{363}$ Minor sources have less stringent requirements than major sources but are required to obtain an approval order as provided in the Utah Administrative Code R307-401. ${ }^{364}$ Utah's Division of Air Quality website lists 1,547 approval orders issued since July 1, 2007. ${ }^{365}$ There are many pre-2007 approval orders, but they are not available in a

358. UTAH ADMIN. CODE r. 307-501-4.

359. r. 307-401, $-403,-405$.

360. Ozone in the Uinta Basin, supra note 352.

361. Title $V$ Operating Permits Issued, UTAH DEP'T ENVTL. QuALITY, http://168.178.3.241:8080/DAQ_NOI/OPS_Issued (last visited Jan. 9, 2018).

362. Id.

363. UTAH ADMIN. CODE r. 307-101-2.

364. r. 307-401.

365. Air Quality, UTAH DEP'T ENVTL. QUALITY, http://168.178.3.241:8080/DAQ_NOI/AOslssuedAll (last visited Jan. 9, 2018). 
DAQ database. ${ }^{366}$ The DAQ has issued approval orders for approximately 920 oil and gas industry sources. ${ }^{367}$

\section{i. Approval Orders}

Utah Administrative Code R307-401 "establishes the application and permitting requirements for new installations and modifications to existing installations throughout the State of Utah." ${ }^{368}$ There is an exemption in R307-4019, discussed below, for small sources. Facilities located in nonattainment or maintenance areas have additional requirements that are found in R307-403, R307405, R307-406, R307-410, R307-420, and R307-421. ${ }^{369}$

Sources must utilize the "Best available control technology" (BACT), which is defined at R307-401-2 as an:

[E]missions limitation (including a visible emissions standard) based on the maximum degree of reduction for each air pollutant which would be emitted from any proposed stationary source or modification which the director, on a case-by-case basis, taking into account energy, environmental, and economic impacts and other costs, determines is achievable for such source or modification through application of production processes or available methods, systems, and techniques, including fuel cleaning or treatment or innovative fuel combustion techniques for control of such pollutant. In no event shall application of best available control technology result in emissions of any pollutant which would exceed the emissions allowed by any applicable standard under 40 CFR parts 60 and 61 . If the director determines that technological or economic limitations on the application of measurement methodology to a particular emissions unit would make the imposition of an emissions standard infeasible, a design, equipment, work practice, operational standard or combination thereof, may be prescribed instead to satisfy the requirement for the application of best available control technology. Such standard shall, to the degree possible, set forth the emissions reduction achievable by implementation of such design, equipment, work practice or operation, and shall provide for compliance by means which achieve equivalent results. ${ }^{370}$

R307-401 applies to any person intending to: "construct a new installation . . . or make modifications or relocate an existing installation . . . or install a control apparatus or other equipment intended to control emissions of air pollutants."371 Additional permitting requirements for new or modified sources may be imposed

366. See id.

367. E-mail from Alan Humpherys, Section Manager, Minor New Source Review, Utah DAQ, to author (May 12, 2017) (on file with author).

368. UTAH ADMIN. CODE r. 307-401-1.

369. Id.

370. UTAH ADMIN. CODE r. 307-401-2.

371. r. 307-401-3(1)(a)-(c). 
based on R307-403, R307-405, and R307-406. ${ }^{372}$ The "[e]xemptions contained in R307-401 do not affect applicability or other requirements under R307-403, R307405 or R307-406," and do not affect "applicability or other requirements under R307-401, unless specifically authorized." ${ }^{\prime 73}$

R307-401-4 provides general requirements that "apply to all new and modified installations, including installations that are exempt from" needing an approval order. ${ }^{374}$ "[C]ontrol apparatus installed on an installation [must be] adequately and properly maintained." ${ }^{375}$ An exempted installation that is not meeting an approval order or State Implementation Plan limitation may be required to "submit a notice of intent and obtain an approval order in accordance with R307401-5 through R307-401-8." 376

A person subject to R307-401-5 must submit a notice of intent to the director of the Division of Air Quality "and receive an approval order prior to initiation of construction, modification or relocation." 377 "The notice of intent shall be in a format specified by the director." ${ }^{378}$ The regulation specifies the content of the notice of intent. ${ }^{379}$ The applicant must receive an approval order prior to construction, modification, or relocation. ${ }^{380}$

The content of the approval order is specified in R307-401-8. Emissions, including fugitive emissions and fugitive dust, must use best available control technology (BACT). ${ }^{381}$ "[F]or a new or modified source in an ozone nonattainment or maintenance area that will emit volatile organic compounds or nitrogen oxides," BACT shall be at least as stringent as any EPA Control Technique Guidance document that is applicable to the source. ${ }^{382}$ It must also meet the following: any requirements applicable to new and modified sources in nonattainment and maintenance areas; PSD requirements including visibility requirements; ozone offset requirements in Davis and Salt Lake Counties; new source performance standards; national emission standards for hazardous air pollutants; and all requirements of the Utah State Implementation Plan. ${ }^{383}$ Moreover, all pollution control equipment must be adequately and properly maintained. ${ }^{384}$ "If the director determines that a proposed stationary source, modification or relocation does not meet the conditions" for an approval order it may not be issued. ${ }^{385}$

A small stationary source is exempted by R307-401-9 from the requirement to obtain an approval order if the following conditions are met:

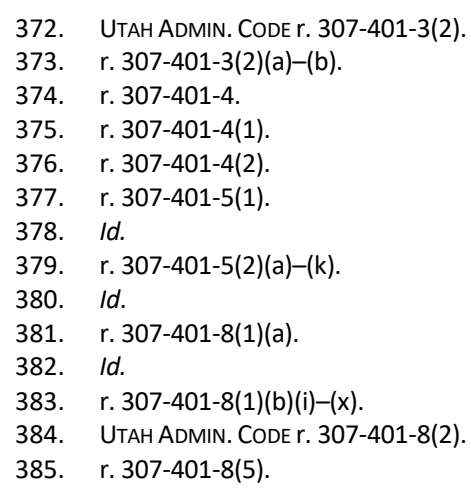


(a) its actual emissions are less than 5 tons per year per air pollutant of any of sulfur dioxide, carbon monoxide, nitrogen oxides, $\mathrm{PM}_{10}$, ozone, or volatile organic compounds;

(b) its actual emissions are less than 500 pounds per year of any hazardous air pollutant and less than 2000 pounds per year of any combination of hazardous air pollutants;

(c) its actual emissions are less than 500 pounds per year of any air pollutant not listed in (a) or (b) above and less than 2000 pounds per year of any combination of air pollutants not listed in (a) or (b) above.

(d) Air pollutants that are drawn from the environment through equipment in intake air and then are released back to the environment without chemical change, as well as carbon dioxide, nitrogen, oxygen, argon, neon, helium, krypton, xenon should not be included in emission calculations when determining applicability under (a) through (c) above. ${ }^{386}$

A source that is exempted from the requirement to obtain an approval order "shall no longer be exempt if actual emissions in any subsequent year exceed the emission thresholds . . .."387 "The director will maintain a registry of sources that are claiming an exemption under R307-401-9." 388 "A stationary source that is not required to obtain a permit under R307-405 for greenhouse gases, as defined in R307-405-3(9)(a), is not required to obtain an approval order for greenhouse gases under R307-401." 389 "The owner or operator of a stationary source of air pollutants that reduces or eliminates air pollutants [may be] exempt from the requirement to submit a notice of intent and obtain an approval order prior to construction." 390

Approval orders issued by the director in accordance with the provisions of R307-401 [must be] reviewed eighteen months after the date of issuance to determine the status of construction, installation, modification, relocation or establishment. If a continuous program of construction, installation, modification, relocation or establishment is not proceeding, the director may revoke the approval order. ${ }^{391}$

\section{ii. General Approval Orders}

In November 2013, a rule was approved that provides for general approval orders (GAOs). ${ }^{392}$ A GAO is an alternative to the standard approval order for similar new or modified sources in a specified source category or for specific types of equipment depending on the regulations promulgated for a source category. ${ }^{393} \mathrm{~A}$

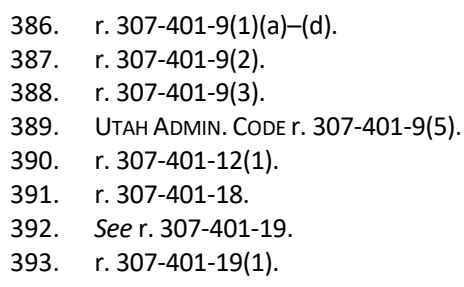


GAO may apply throughout the state or can be limited to a specific area. ${ }^{394}$ To obtain a GAO, an applicant must meet all applicable requirements of R307-401-8. ${ }^{395}$ This includes the need to utilize BACT and provide a representative impact analysis. The director may require any source that has applied for a GAO to submit a notice of intent and obtain an individual approval order if the director determines that the source does not meet the criteria specified in the GAO rule, if modifications were made to the source that were not authorized by the GAO, or if a source is violating the law. ${ }^{396}$ "A source may make modifications only as authorized by the approved general approval order. Modifications outside the scope authorized by the approved general approval order shall require a new application for either an individual approval order under R307-401-8 or a general approval order under R307-401-19."397

Utah's Division of Air Quality has developed this program for the oil and gas industry. ${ }^{398}$ But, as of May 2017, only one GAO has been issued to an oil and gas industry source. ${ }^{399}$ Crude Oil and Natural Gas Well Site and Tank Battery GAOs are available for facilities that process up to 50,000 barrels of crude oil and condensate combined per year. ${ }^{400}$ Storage tanks must route volatile organic compounds (VOCs) to a process unit where they are recycled, incorporated into a product, or destroyed. ${ }^{401}$ Maximum "tank capacity is limited to 550 barrels, and the maximum site-wide tank capacity is limited to 2,200 barrels." 402 VOC and HAP emissions from dehydrators and natural gas-driven pneumatic pumps have similar control requirements. ${ }^{403}$ "Any VOC control device [must] have a minimum control/destruction efficiency of 98 percent []" and operate with no visible emissions. ${ }^{404}$ Natural gas driven pneumatic "controllers must either be low bleed or have VOC emissions controlled." ${ }^{405}$ Stationary engines, boilers, and heaters must use natural gas or liquefied petroleum gas (LPG) as fuel. ${ }^{406} \mathrm{~A}$ leak detection and repair program that meets the EPA's requirements is required. ${ }^{407}$

\footnotetext{
394. Id.

395. r. 307-401-19(2).

396. r. 307-401-19(6)(a)(i)-(v).

397. UTAH ADMIN. CODE $r$. 307-401-19(8). A GAO requires an applicant to submit form 1 that is available at https://deq.utah.gov/forms/air/docs/2011/100ct/Form1NOI.pdf.

398. General Approval Orders, UTAH DEP'T ENVTL. QUALITY, https://deq.utah.gov/Permits/GAOs/gaos.htm (last visited Jan. 9, 2018).

399. Email from Humpherys, supra note 367. Utah's GAOs may be found at https://deq.utah.gov/Permits/GAOs/gaos.htm.

400. General Approval Order (GAO)-Uinta Basin, UTAH Dep'T EnVtL. QUaLITY, https://deq.utah.gov/locations/U/uintahbasin/ozone/strategies/gao.htm (last visited Jan. 9, 2018).

401. Id.

402. Id.

403. Id.

404. Id.

405. Id.

406. General Approval Order (GAO)-Uinta Basin, supra note 400.

407. Id.
} 


\section{iii. Compliance}

Utah oil and gas operation compliance is regulated by the Department of Environmental Quality, Division of Air Quality, and the Department of Natural Resources, Division of Oil, Gas and Mining. The Division of Oil, Gas and Mining (DOGM) made 8,758 well inspections in 2016. ${ }^{408}$ However, DOMG and its Board do not regulate air emissions. It does have jurisdiction over flaring in order to preserve the resource, but no order allowing or limiting flaring has ever been issued based on air quality issues. ${ }^{409}$

Most air pollution compliance activities involving the oil and gas industry are the responsibility of Utah DAQ's Minor Source Compliance Section, which has three full-time inspectors assigned to oil and gas operations. ${ }^{410}$ During the 2016 fiscal year, there were 114 full-compliance evaluations. ${ }^{411}$ These evaluations involve preinspection preparation, followed by an unannounced site inspection. ${ }^{412}$ At the site, each piece of equipment listed in the permit is inspected and visible emission observations are made at emission points. ${ }^{413}$ An Infrared (IR) camera is used to search for VOC leaks. ${ }^{414}$ This is followed by a post-inspection meeting with a representative of the facility at which the source's need for further action, if any, is discussed. ${ }^{415}$

If there are compliance issues, a compliance advisory letter is sent to the source, and additional information may be requested. ${ }^{416}$ If it is determined that the source is violating an applicable requirement, a settlement agreement is issued and the source must act to bring the facility into compliance. ${ }^{417}$ In 2015, ten early settlement agreements with sanctions were issued, and in 2016, there were 21 such agreements. ${ }^{418}$ Violations included the use of un-permitted equipment, exceeding production limits, poor maintenance, and VOC leaks. ${ }^{419}$ The penalties imposed ranged from $\$ 359$ to $\$ 10,000$, with the majority of the penalties below $\$ 1000 .{ }^{420}$ There have been no civil or criminal enforcement actions in the past five years. ${ }^{421}$

408. Well Inspections, UtAH Dep'T Nat. Res., DIv. OIL, GAS \& Mining, https://oilgas.ogm.utah.gov/oilgasweb/statistics/well-inspect.xhtml (last visited Jan. 9, 2018).

409. E-mail from Thomas Mitchell, Senior Counsel, State of Utah, Sch. and Inst. Tr. Lands Admin., to author (May 10, 2017) (on file with author).

410. E-mail from Jay P. Morris, Manager, Minor Source Compliance Section, DAQ, to author (May 17,2017 ) (on file with author).

411. Id.

412. Cindy Beam, Air Quality: Inspectors Ensure Compliance, UTAH DEPT. ENVTL. QUALITY, https://deq.utah.gov/news/permit-compliance (last updated Aug. 10, 2017).

413. Id.

414. Email from Jay P. Morris, supra note 410.

415. Id.

416. Id.; see also Stationary Sources Compliance, UTAH DEP'T ENVTL. QUALITY, https://deq.utah.gov/Compliance/compliance/air/stationarysource/index.htm (last visited Jan. 9, 2018).

417. Email from Jay P. Morris, supra note 410.

418. Id.

419. Id.

420. Id.

421. Id. 


\section{iv. Proposed Permit Changes}

Oil and gas sources are primarily minor sources or exempt sources under Utah rules. They make up over half the minor source permit requests received by Utah's DAQ. ${ }^{422}$ Because of the nature of the oil and gas industry, the permits that are issued are virtually identical. ${ }^{423}$ For this reason, the Utah Air Quality Board on September 6, 2017, approved for public comment a number of proposed changes to the permitting process. ${ }^{424}$ The proposal would replace the existing source-bysource permitting process with a permit-by-rule (PBR) system. ${ }^{425}$ To implement PBR, DAQ has proposed new rules and amendments to a number of existing rules. ${ }^{426}$ The PBR will apply statewide and will require BACT that currently applies to sources that require new source review (NSR) permits. ${ }^{427}$ An important part of the proposed rules is the requirements in R307-150-1 that will require emission inventory reports from most small sources. However, there are exemptions from new technologybased requirements for sources that already have approval orders. ${ }^{428}$

\section{B. California}

California has more than 50,000 active oil wells, "about 1,500 active natural gas wells, and nearly 500 underground natural gas storage wells[,]' although about ninety percent of its natural gas comes from other states. ${ }^{429}$ It also has 215,000 miles of natural gas pipelines for transmission and distribution, twenty-two compressor stations, and 25,000 metering and regulating stations. ${ }^{430}$ California regulates air pollution at the state level through its Air Resources Board, but much of the regulation of the oil and gas industry is the responsibility of local air districts, which regulate stationary sources. ${ }^{431}$ There are thirty-five local air districts in California. ${ }^{432}$ These districts regulate VOCs and $\mathrm{NO}_{\mathrm{x}}$ emissions to control groundlevel ozone. ${ }^{433}$ These controls reduce the associated methane emissions, but the local districts do not directly regulate methane. ${ }^{434}$

\footnotetext{
422. Title $V$ Operating Permits Issued, UTAH DeP'T ENVTL. QUaLITY, http://168.178.3.241:8080/DAQ_NOI/OPS_Issued (last updated Feb. 8, 2016).

423. See id.

424. Utah Dep't Envtl. Quality, Utah Air Quality Board Meeting Final Agenda, at item 5 (Sept. 6 , 2017), https://utah.gov/pmn/files/326737.pdf\#page=30.

425. Id.

426. See id.

427. Id.

428. Id.

429. ShORT-LIVEd Climate PollutANT Reduction StRATEGY, supra note 2, at 78-79. The California data on natural gas wells appears to be based on 2010 information. The ElA says there were 4,210 producing gas wells in 2015. U.S. Energy Info. Admin., Natural Gas, Number of Producing Gas Wells, ElA, https://www.eia.gov/dnav/ng/ng_prod_wells_s1_a.htm (last visited Jan. 9, 2018).

430. ShORT-Lived Climate Pollutant Reduction Strategy, supra note 2, at 79.

431. Id. at 79 .

432. CAL. AIR RES. BD., California Local Air District Directory, CA.Gov, https://www.arb.ca.gov/capcoa/roster.htm (last visited Jan. 9, 2018).

433. Short-Lived Climate Pollutant Reduction StRATEGy, supra note 2, at 79.

434. Id.
} 
In July 2016, the California Air Resources Board (CARB) proposed a state rule that would reduce methane emissions from oil and natural gas facilities by fortyfive percent over nine years. ${ }^{435}$ The proposed regulation requires vapor collections from various sources of oil and gas operations. ${ }^{436}$ It requires leak detection and repair. ${ }^{437}$ It requires "no bleed" pneumatic devices and pumps. ${ }^{438}$ It requires the development of a methane monitoring program. ${ }^{439}$ This regulation builds on the programs of some existing air pollution control districts but covers many components not covered by local district programs. ${ }^{440}$

On March 23, 2017, CARB approved a new methane regulation that will be phased in between 2018 and 2020. ${ }^{441}$ The aim is to reduce the 118 Million Metric Tons $\mathrm{CO}_{2 \mathrm{e}}\left(\mathrm{MMTCO}_{2 \mathrm{e}}\right)$ of methane to $71 \mathrm{MMTCO}_{2 \mathrm{e}}$ by 2030 , which is a forty percent reduction. ${ }^{442}$ The regulation limits both "intentional . . . and unintentional . . . emissions from active and idle equipment and operations." ${ }^{443}$ It has leak detection and repair requirements that include daily inspections and quarterly leak testing. ${ }^{444}$ It has requirements for vapor control and enhanced monitoring and reporting requirements. ${ }^{445}$

California is also moving to create new regulations to control underground storage facilities. ${ }^{446}$ On July 8, 2016, California's Department of Conservation, Division of Oil, Gas, and Geothermal Resources, released a pre-rulemaking draft regulation to update its gas storage program. ${ }^{447}$ The California Public Utility Commission is working to adopt rules to prevent gas leaks from the transmission, distribution, and storage processes as directed by Senate Bill $1371 .^{448}$

The oil and gas sector in California is responsible for four percent of the methane emissions. The new methane rule, when combined with the regulations by the California Public Utilities Commission governing transport, is expected to reduce methane emissions from the oil and gas industry by fifteen percent. ${ }^{449}$ On

435. See CAL. AIR ReS. BD., Proposed Regulation Order, Subch. 10: Climate Change, Art. 3: Greenhouse Gas Emission Standards for Crude Oil and Natural Gas Facilities, (proposed Apr. 22, 2015), https://www.arb.ca.gov/cc/oil-gas/meetings/Draft_Regulatory_Language_4-22-15.pdf. Current regulations can be found at CAL. CODE REGS. tit. 17, §§ 95665-95677 (2017).

436. Short-Lived Climate Pollutant Reduction StRategy, supra note 2, at 80.

437. Id.

438. Id.

439. Id.

440. Id.

441. Carolyn Whetzel, California Methane Rule First Stab at Climate 'Super Pollutants', ENERGY \& Climate Rep. (BNA), BLoomberg LAW, Mar. 24, 2017, ECR Issue No. 56.

442. CAL. RES. AIR BD., CARB Approves Rule for Monitoring and Repairing Methane Leaks from Oil and Gas Facilities, CA.GOv (Mar. 23, 2017), https://www.arb.ca.gov/newsrel/newsrelease.php?id=907; see also SHORT-Lived Climate PolLutANT Reduction Strategy, supra note 2, at 6 tbl.1.

443. M. Clare Ellis, California Ramps Up Methane Regulation, NiCKEL ReP. Hunton \& WilLIAMs (Apr. 11, 2017), https://www.huntonnickelreportblog.com/2017/04/california-ramps-up-methane-regulation/.

444. Id.

445. $I d$.

446. Short-Lived Climate Pollutant Reduction Strategy, supra note 2, at 80.

447. CAl. DeP'T Conservation DIV. OIL, Gas \& GeOthermal ReS., Underground Gas Storage Permanent Rulemaking, CAL. DEP'T CONSERVATION, http://www.conservation.ca.gov/dog/general_information/Pages/UGSRules.aspx (last visited Jan. 9, 2018).

448. Short-Lived Climate Pollutant Reduction StRATEgy, supra note 2, at 81.

449. Id. 
June 15, 2017, the California Public Utilities Commission adopted the Natural Gas Leak Abatement Program, which augments a 2017 CARB rule designed to reduce methane emissions from oil and gas production facilities by forty percent below 2013 levels by $2030 .{ }^{450}$ In addition, oil and gas wells in California are subject to the Department of Conservation, Division of Oil, Gas \& Geothermal Resources rules governing the drilling, operation, and maintenance related to oil and gas operations. ${ }^{451}$

California's thirty-five Air Pollution Control Districts (APCD) and Air Quality Management Districts (AQMD) have most of the authority over stationary sources of air pollution. ${ }^{452}$ One of the most active districts is the South Coast Air Quality Management District (SCAQMD) that covers the Los Angeles area. ${ }^{453}$ Its rules include § 1148-Thermally Enhanced Oil Recovery Wells; § 1148.1-Oil and Gas Production Wells; and § 1149-Storage Tank and Pipeline Cleaning and Degassing. Rule 1148.1 requires reductions in VOCs, Toxic Air Contaminants (TAC) and Total Organic Compounds (TOC) ${ }^{454}$ The District's rules to limit emissions of VOCs also reduce methane emissions that are mixed with VOC emissions. These rules are applicable "to onshore producing wells, well cellars, and produced gas handling operations ... . where petroleum and processed gas are produced, gathered, separated, processed, and stored." ${ }^{\prime 45}$ On July 7, 2017, the SCAQMD imposed higher fees on unplanned and repeat flaring events. ${ }^{456}$ The updated rule has more stringent notification requirements and new emissions factors for vented gases and includes the EPA's most recent requirements concerning flaring. ${ }^{457}$ The rule applies to eight oil refineries and four other sources in the Los Angeles area. ${ }^{458}$

\section{Colorado}

In Colorado, crude oil production quadrupled from 2010 to 2015 and then decreased somewhat in 2016 as crude oil prices declined. ${ }^{459}$ Substantial oil production comes from the Denver-Julesburg area in northeastern Colorado, which results in the second highest VOC emissions in the western states that are discussed in this article. ${ }^{460}$ The other important oil and gas production area is the Piceance

450. Carolyn Whetzel, California Utilities Must Reduce, Fix Pipeline Methane Leaks, ENERgY \& Climate Rep. (BNA), June 15, 2017, BLOOMBERG LAW, ECR Issue No. 115.

451. Cal. Dep't Conservation Div. Oll, Gas \& Geothermal Res., Welcome to the Division of Oil, Gas, \& Geothermal Resources, CAL. DEP'T CONSERVATION, http://www.conservation.ca.gov/dog/ (last visited Jan. 9, 2018).

452. CAL. AIR RES. BD., California Air District Map for District Rules, CA.Gov, https://www.arb.ca.gov/drdb/dismap.htm (last updated Mar. 23, 2012).

453. See SOUTH COAST AQMD, www.aqmd.gov (last visited Jan. 9, 2018).

454. South Coast Air Quality Mgmt. Dist., Reg. XI, r. 1148.1 (2015).

455. South Coast Air Quality Mgmt. Dist., Reg. XI r. 1148.1(b).

456. Carolyn Whetzel, Los Angeles Refineries to Pay More for Excessive Flaring, ST. ENVTL DAILY (BNA), July 10, 2017, BLOOMBERG LAW, SED Issue No. 130.

457. Id.

458. Id.

459. U.S. ENERgY INFO. ADMIN., Colorado: Profile Analysis, EIA, https://www.eia.gov/state/analysis.php?sid=CO (last updated Dec. 21, 2017) [hereinafter Colorado Profile]. 460. Milford, supra note 60 , at 6 tbl.1. 
Basin in western Colorado. ${ }^{461}$ Both of these oil-producing areas have substantial natural gas production as well. ${ }^{462}$ Additional natural gas production comes from the San Juan Basin, which extends into New Mexico. ${ }^{463}$ In 2017, Colorado had 23,279 active producing oil and gas wells. ${ }^{464}$

Oil and gas operations are regulated by the Colorado Oil and Gas Conservation Commission (COGCC). ${ }^{465}$ Air quality regulations are adopted by the Air Quality Control Commission and are administered by the Air Pollution Control Division (APCD) within the Department of Public Health and Environment. ${ }^{466}$ Construction permits are required for new or modified sources with emissions above specified thresholds. ${ }^{467}$ VOC and NOx have emission limits based on whether the location is nonattainment or attainment or maintenance areas. ${ }^{468}$ Minor sources must install Reasonably Available Control Technology (RACT). ${ }^{469}$ Existing oil and gas production equipment is subject to regulation for ozone precursors. ${ }^{470}$ Colorado's emission regulations for controlling VOCs from oil and gas operations include oil and gas production operations, natural gas compression stations, and natural gas drip stations (aka natural gas condensate: white gas). ${ }^{471}$

On February 23, 2014, Colorado became the first state to address methane emissions from the oil and gas industry in addition to the previously regulated VOCs. ${ }^{472}$ Key elements of the Colorado rule were subsequently adopted by Wyoming. The rule was enacted by Colorado's Air Quality Control Commission (AQCC) with the support of three of the state's largest producers: Anadarko Petroleum, Noble Energy and Encana, and numerous environmental groups, but it was opposed by the Colorado Oil and Gas Association and the Colorado Petroleum Association. ${ }^{473}$ It is projected to reduce VOCs and methane equal to the emissions of all cars and trucks in Colorado. ${ }^{474}$

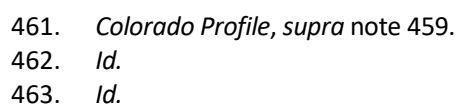

471. § 1001-9:XII(A)(1) (Volatile Organic Compound Emissions from Oil and Gas Operations). See generally Oil and Gas Air Emissions Requirements (Regulation 7 Section XVII), Colo. DeP'T PUB. HeALTH \& ENV'T, https://www.colorado.gov/pacific/cdphe/summary-oil-and-gas-emissions-requirements (last visited Jan. 9, 2018).

472. Lauren Whittenberg \& Alison Omens, In Colorado, a Breakthrough for Cleaner Air and Safer Climate, EDF.ORG (Feb. 23, 2014), https:www.edf.org/media/Colorado-breakthrough-cleaner-air-and-saferclimate.

473. Bruce Finley, Colorado Adopts Tougher Air Rules for Oil, Gas Industry, DENVER POST, http://www.denverpost.com/2014/02/23/colorado-adopts-tougher-air-rules-for-oil-gas-industry (last updated Apr. 27, 2016).

474. Whittenberg \& Omens, supra note 472. 
The Colorado AQCC added methane to its list of regulated pollutants by approving a new Regulation Number 7, codified at 5 CCR $\S 1001-9.475$ It replaced the prior rule's use of the term VOC with the term hydrocarbons, which has the effect of making methane a regulated pollutant. ${ }^{476}$ Section 1001-9 includes a number of subsections applicable to the oil and gas industry, particularly subsection XII (Volatile Organic Compound Emissions from Oil and Gas Operations). ${ }^{477}$ In addition, AQCC Regulation Number 6, codified at 5 CCR $\S 1001-5$, adopts EPA's NSPS for the oil and gas industry. ${ }^{478}$ However, the Colorado rules in 5 CCR § 1001-8 impose additional requirements beyond the EPA's, and they are enforceable based on Colorado law. ${ }^{479}$

Section 1001-9 requires emissions of hydrocarbons to be reduced by ninetyfive percent from centrifugal compressors, new and recompleted wells, glycol natural gas dehydrators, and storage tanks-with various phase-in dates. ${ }^{480}$ It also requires emissions to be reduced from venting and flaring. ${ }^{481}$ It requires companies to detect leaks and repair them and to capture ninety-five percent of VOC and methane emissions. ${ }^{482}$ To implement the new requirements, the rule adds more stringent inspection requirements. ${ }^{483}$

In 2012, Colorado APCD had eight inspectors that focused on the oil and gas sector, and COGCC employed 16 field inspectors to supervise more than 49,000 active oil and gas wells. ${ }^{484}$ To inspect each well once a year would require each inspector to evaluate a well about every hour of the work year. How inspectors will evaluate compliance with these complex regulations aimed at myriad components used in the oil and gas processing with the state governments limited personnel and resources is a mystery.

\section{New Mexico}

New Mexico is the eighth most important supplier of net energy in the United States. ${ }^{485} \mathrm{It}$ is the state that has the second highest number of oil and gas leases on federal land. ${ }^{486}$ Its San Juan Basin in the northwest corner and the Permian Basin in the southeast, which straddles Texas and New Mexico, are two of the most

475. 2 COLO. CODE REgs. $§ 1001-9$

476. Id.

477. See id.

478. Compare 2 COLO. CODE REGS. § 1001-5:3(A)(I), with 40 C.F.R. $\S 60.5430$ (2017).

479. 2 COLO. CODE REGS. $\S 1001-8$.

480. §1001-9.

481. Id.

482. Finley, supra note 473.

483. Kristine Baumstark, New Colorado Methane Emissions Rules, KBH CTR. FOR ENERGY, L. \& Bus. (Mar. 24, 2014), https://www.kbhenergycenter.utexas.edu/2014/03/24/new-colorado-methaneemissions-rules/.

484. Milford, supra note 6060, at 25, 27.

485. U.S. ENERgy INFo. Admin., U.S. States State Profile and Energy Estimates, Rankings: Total Energy Production, 2015 (Trillion Btu), EIA, https://www.eia.gov/state/rankings/\#/series/101 (last visited Jan. 9, 2018).

486. U.S. Energy INFo. Admin., New Mexico State Profile and Energy Estimates: Profile Analysis, EIA, https://www.eia.gov/state/analysis.php?sid=NM (last updated Jan. 19, 2017). 
important oil and gas fields in the U.S. ${ }^{487}$ In 2015, the state had 40,578 producing natural gas wells. ${ }^{488}$ The Permian Basin may become even more important because, in February 2017, ExxonMobil paid almost \$6 billion for drilling rights to over 275,000 acres in the Basin. ${ }^{489}$ Exxon's XTO Energy, Inc. will deploy fifteen new rigs with the goal of producing a twenty percent per year increase in crude oil output from its properties through 2025. ${ }^{490}$ Between May 2016 and January 2017, more than half the horizontal drilling rigs in the U.S. were deployed to the Permian Basin. ${ }^{491}$

The oil and gas industry in New Mexico is subject to regulations issued by the Oil Conservation Commission (OCC). ${ }^{492}$ The regulations are administered by the state's Oil Conservation Division (OCD) within the Minerals and Natural Resources Department. ${ }^{493}$ The OCD is minimally funded and has about fourteen inspectors to supervise compliance from about 60,000 wells. ${ }^{494}$ OCD can use Rule 5.9 to essentially put the operator out of business by denying an operator permits to drill new wells, transport oil, and inject waste water underground. ${ }^{495}$ However, OCD's enforcement power to deal with less serious violations was limited by New Mexico's Supreme Court in the 2009 decision of Marbob Energy Corp. v. New Mexico Oil Conservation Commission. ${ }^{496}$ Marbob Energy, an oil and gas producer, challenged New Mexico Administrative Code $\S$ 19.15.14.1227 giving the OCC and the OCD the authority to assess civil penalties and impose other sanctions for violations of the Oil and Gas Act. ${ }^{497}$ The District Court affirmed the order and the case eventually went to the State's Supreme Court. ${ }^{498}$

The New Mexico Supreme Court held that the specific provisions of "[s]ection 70-2-28 require that the Attorney General . . bring an action in court to assess civil penalties for violations of the Act, and [any associated] rules, orders, and regulations ...." 499 "The Commission was created by Section 70-2-4 of the [Oil and Gas] Act and has two primary duties regarding the conservation of oil and gas:

487. Bureau OF LAND MgMt., BLM New Mexico Oil and Gas, BLM.gov, https://www.blm.gov/programs/energy-and-minerals/oil-and-gas/about/new-mexico (last visited Jan. 9, 2018). For a discussion of oil and gas activities in the San Juan Basin see Diné Citizens Against Ruining Our Env't v. Jewell, 839 F.3d 1276 (10th Cir. 2016).

488. U.S. ENERgy INFo. AdMIN., Natural Gas, Number of Producing Gas Wells, EIA, https://www.eia.gov/dnav/ng/ng_prod_wells_s1_a.htm (last visited Jan. 9, 2018).

489. Joe Carrol, Why Exxon Is Giving XTO, Its Shale Unit, a Long Leash, ENERGY \& CLIMATE ReP. (BNA), Apr. 21, 2017, BLOOMBERg LAW, ECR Issue No. 76.

490. Id.

491. Clifford Krauss, Land Rush in Permian Basin, Where Oil is Stacked Like a Layer Cake, N.Y. TIMES (Jan. 17, 2017), https://www.nytimes.com/2017/01/17/business/energy-environment/exxon-mobilpermian-basin-oil.html?mcubz=0.

492. Mónica Ortiz Uribe, State Oil Inspectors in New Mexico Overwhelmed, FronTERAS (Jan. 8, 2015), http://www.fronterasdesk.org/content/9903/state-oil-inspectors-new-mexico-overwhelmed.

493. Id.

494. Id.

495. Mónica Ortiz Uribe, New Mexico's Oil Regulators Have Limited Enforcement Tools, FrONTERAS (Jan. 6, 2015), http://www.fronterasdesk.org/content/9901/new-mexicos-oil-regulators-have-limitedenforcement-tools.

496. 206 P.3d 135, 143 (N.M. 2009).

497. Id. at 137,137 n.1.

498. Id. at 137.

499. Id. 
prevention of waste and protection of correlative rights." ${ }^{\prime 500}$ The OCC may also make rules and regulations to implement and enforce the Act. ${ }^{501}$ The OCD was given authority to regulate by the Commission on November $10,2005 .{ }^{502}$ However, the Supreme Court held that $O C D$ did not have authority under Act to impose civil penalties. ${ }^{503}$

The parties' dispute involved conflicting interpretations of the statute. ${ }^{504}$ According to Marbob, Section 70-2-28 mandated that the Attorney General bring suit to assess the penalties. ${ }^{505}$ The only penalty provision that directly concerned this case was Section 70-2-31(A), which provides that "[a]ny person who knowingly and willfully violates any provision of the Oil and Gas Act ... or any provision of any rule or order issued pursuant to that act shall be subject to a civil penalty of not more than one thousand dollars $(\$ 1,000)$ for each violation." ${ }^{506}$ The Commission argued that the OCD and the Commission may assess penalties by virtue of the broad statutory authority granted to them in Sections $70-2-6$ and -11 to enforce the Act. ${ }^{507}$

The court agreed with Marbob that the Attorney General is to establish liability and assess the civil penalties authorized under the Act based on the plain language of the statute. ${ }^{508}$ The result of this case was to make it nearly impossible to enforce oil and gas regulations. The under budgeted and understaffed OCD had to forward any civil penalty case to the Attorney General's Office. ${ }^{509}$ Because civil penalties were limited to $\$ 1,000$ per violation, these cases were a low priority for the use of the finite budget of the prosecutors. ${ }^{510}$ It has been reported that such cases are rarely brought. ${ }^{511}$

Subsequently, the New Mexico legislature increased the civil penalty provision to a maximum of $\$ 15,000$ per day for violation of an air quality regulation, a permit condition, or an emergency order, but civil penalties continue to be enforceable only by the Attorney General's Office. ${ }^{512}$ New Mexico's Legislature also added section 74-2-12 that provides for the issuance of a compliance order for violation of the Air Quality Control Act. ${ }^{513}$ Violation of a compliance order can lead to a penalty of up to $\$ 15,000$ a day. ${ }^{514}$ In addition, a field citation program provides for civil penalties up to $\$ 1,000$ per day of violation. ${ }^{515}$ The statutes also provide for criminal

500. Id. at 137-38.

501. N.M. STAT. ANN. § 70-2-11 (West 2017).

502. Marbob, 206 P.3d at 138.

503. Id. at 143 .

504. Id. at 139 .

505. Id.

506. N.M. STAT. ANN. § 70-2-31(A).

507. Marbob, 206 P.3d at 139.

508. Id. at $140-43$.

509. Id. at 143.

510. Mónica Ortiz Uribe, Oil and Gas Regulation in New Mexico Outdated, Fronteras (Jan. 5, 2015), http://www.fronterasdesk.org/content/9900/oil-and-gas-regulation-new-mexico-outdated.

511. Id.

512. N.M. StAT. ANN. § 74-2-12.1(A) (West 2017).

513. §74-2-12.

514. $\S 74-2-12(B)$.

515. § 74-2-12(D). 
penalties that may include a fine of up to $\$ 10,000$ per day or imprisonment for up to 18 months, or both. ${ }^{516}$

The New Mexico Environment Department (NMED) is responsible for protecting and restoring New Mexico's environment. ${ }^{517}$ It has a Petroleum Storage Bureau within the NMED that has a mandate to reduce, mitigate and eliminate releases of petroleum products from storage tanks. ${ }^{518}$ Air quality is the responsibility of the Air Quality Bureau within NMED. ${ }^{519}$ It engages in strategic planning, issues air quality construction and operating permits, ensures compliance and participates in the usual activities of a state air pollution control agency. ${ }^{520} \mathrm{It}$ has statewide jurisdiction except for Bernalillo County and Tribal Lands. ${ }^{521}$ Its authority is provided by New Mexico statutes, Title 74, Chapter $2 .{ }^{522}$

Section 74-2-5 provides for the Environmental Improvement Board to prevent or abate air pollution, and it gives the Board rulemaking authority. ${ }^{523}$ Section $74-2$ 5.3 gives the Board the power to regulate emissions that cause or contribute to ozone concentrations that exceed ninety-five percent of the national ambient air quality standards (NAAQS) for the ozone. ${ }^{524}$ This limits the areas subject to the Board's regulatory authority. Regulations to implement the air pollution laws are found in the New Mexico Administrative Code 20.2. ${ }^{525}$ There are almost no regulations specifically aimed at the oil and gas industry. One exception is section 20.2.38, which deals with the control of hydrocarbon storage facilities. ${ }^{526}$ Section 20.2.100, dealing with the state's greenhouse gas reduction program was repealed. 527

\section{E. Wyoming}

In 2015, Wyoming had 25,279 producing natural gas wells. ${ }^{528}$ Wyoming ranked eighth in the nation in crude oil production, and it ranked fourth in natural gas production in 2013. ${ }^{529}$ Campbell County, followed by Converse and Park Counties, were the leading oil producers. ${ }^{530}$ Sublette County was the leading

516. $\S 74-2-14$.

517. N.M. ENVT'L DeP'T, About NMED, ENV.NM.Gov, https://www.env.nm.gov/about-us/ (last visited Jan. 9, 2018).

518. See generally N.M. Code R. § 20.5.1-.18 (2017) (regulations for petroleum storage tanks).

519. N.M. STAT. ANN. § 74-2-5.1.

520. N.M. ENV'T DEP'T, Welcome to the Air Quality Bureau (AQB) of the New Mexico Environment Department, https://www.env.nm.gov/air-quality/ (last visited Jan. 9, 2018).

521. Id.

522. N.M. Stat. Ann. § 74-2.

523. § $74-2-5$.

524. §74-2-5.3.

525. N.M. CODE R. § 20.2 (2017).

526. §20.2.38.

527. § $\$ 20.2 .100$ (repealed 2012).

528. U.S. Energy INFo. Admin., Natural Gas: Number of Producing Gas Wells, elA, https://www.eia.gov/dnav/ng/ng_prod_wells_s1_a.htm (last visited Jan. 9, 2018).

529. Wro. St. GEOLOGICAL SURV., Wyoming Oil \& Gas Facts, wsGs.wYo.gov, http://www.wsgs.wyo.gov/energy/oil-gas-facts (last visited Jan. 9, 2018) [hereinafter Wyoming Oil \& Gas Facts].

530. RANIE LYNDS \& RACHel TONER, WYOMING'S OIL AND GAS RESOURCES, 1, 2 (2015). 
producer of natural gas, followed by Sweetwater and Johnson Counties. ${ }^{531}$ The Pinedale field was the most productive natural gas field. ${ }^{532}$ Wyoming has $2.5 \%$ of the nation's petroleum reserves and $10.6 \%$ of its dry natural gas reserves. ${ }^{533}$

Wyoming's laws dealing with oil and gas operations are found in the Wyoming Code, Title 30, Chapter 5. ${ }^{534}$ The Wyoming Oil and Gas Conservation Commission (WOGCC) issues drilling permits and enforces the oil and gas laws and regulations. ${ }^{535}$ It issues regulations and orders pursuant to the authority provided by Wyoming Statute section 30-5-104(c) \& (d). WOGCC has issued numerous guidelines and policy statements, including information on best management practices related to oil and gas operations. ${ }^{536}$ Their operating permit requirements apply to any source as defined in the regulations. ${ }^{537}$ The Jonah Interagency Mitigation and Reclamation Office (JIO), a subsidiary of BLM, provides management assistance for the Jonah Natural Gas Field. ${ }^{538}$ The Powder River Interagency Working Group coordinates the permitting and monitoring of natural gas development in the Powder River Basin. ${ }^{539}$

Wyoming law provides for the WOGCC to seek an injunction and civil penalties for the violation of any provision of the statute or regulation through a suit brought in the appropriate district court. ${ }^{540}$ Penalties are up to $\$ 5,000$ per day of violation, but knowing and willful violations can result in a civil penalty up to $\$ 10,000$ per day. ${ }^{541}$ Any person that makes a false report is guilty of a misdemeanor and can face up to a $\$ 5,000$ fine or imprisonment for up to six months, or both. ${ }^{542}$ Any person or corporation violating the statute, rules or a lawful order shall upon conviction be fined up to $\$ 500$ or be imprisoned for up to six months. ${ }^{543} \mathrm{~A}$ violation of Wyoming Statute 30-5-119 involving the excess flaring of natural gas subjects the violator to an additional penalty, ten percent of the civil penalty or $6.25 \%$ of the value of the gas flared or vented, whichever is greater. ${ }^{544}$ Wasting natural gas, by burning or venting it without properly using the gas it is prohibited. ${ }^{545}$ Wasting natural gas is a misdemeanor and is punishable by a fine of up to $\$ 1,000$ per day of violation. ${ }^{546}$

531. Id. at 3.

532. Wyoming Oil \& Gas Facts, supra note 529.

533. Id.

534. WYo. STAT ANN. §§ 30-5-100 to -128 (2017).

535. WYo. STAT ANN. § 30-5-104(d)(i) (West 2017); see also INTERMOUNTAIN OIL \& GAS BMP PROJECT, Wyoming Laws, http://www.oilandgasbmps.org/laws/wyoming_law.php (last visited Jan. 9, 2018); Wro. OIL \& GAS CONSERVATION COMm'N, Oil and Gas, Wogcc.wyo.gov, http://wogcc.state.wy.us/ (last visited Nov. 17, 2017).

536. Wyo. StAT AnN. § 30-5-104(d)(i). See also Intermountain OIL \& GAS BMP PROJeCt, supra note 535.

525. See INTERMOUNTAIN OIL \& GAS BMP PROJECT, supra note 535.

526. Id.

539. Id.

540. WYO. STAT ANN. § 30-5-114.

541. §30-5-119(a).

542. §30-5-119(b).

543. Id.

544. § 30-5-120(a).

545. § 30-5-121.

546. §30-5-123. 
Air quality regulations are promulgated by Wyoming's Environmental Quality Council and are administered by the Wyoming Air Quality Division (WAQD). ${ }^{547}$ Permit requirements are found in chapter 6 with $\S 2$ dealing with permits for construction and modifications of existing facilities and $\S 3$ dealing with operating permits. ${ }^{548}$ Much of the oil and gas industry, however, does not meet the emissions threshold to be subject to the requirements applicable to major sources. WAQD has issued Oil and Gas Production Facilities Chapter 6, Section 2 Permitting Guidance, which helps explain the applicable air quality standards and regulations. ${ }^{549}$ In addition to WAQD requirements, the Wyoming regulations incorporate by reference the federal requirements imposed by the Code of Federal Regulations (CFRs). ${ }^{550}$

Chapter $1, \S 7$ establishes a greenhouse gas permitting program with requirements found in chapter $6, \S \S 3$ and $4 .{ }^{551}$ Preconstruction permits are required for greenhouse gas sources that are subject to the PSD requirements of chapter $6, \S 4 .{ }^{552}$ This allows most oil and gas production facilities to avoid GHG requirements because their emissions are below the trigger point for PSD permitting. Sources that emit greenhouse gases may be subject to operating permit requirements. ${ }^{553}$ Operating permits are required for sources that are major based on CAA $\S \S 111$ or $112 .{ }^{554}$ Major sources are defined as those with the potential to emit 100 tons per year (tpy) or more of any air pollutant or 10 tpy of any HAP or 25 tpy of aggregated HAPs. ${ }^{555}$ However, the regulations limit the ability of the government to aggregate emissions from the oil and gas industry. ${ }^{556}$ This results in few oil and gas activities being subject to the need for a CAA title $V$ operating permit.

VOC sources are subject to BACT requirements. ${ }^{557}$ Flares cannot exceed $20 \%$ opacity. ${ }^{558}$ If a smokeless flare is required, visible emissions are limited to five minutes during any two consecutive hours. ${ }^{559}$

Nonattainment areas are subject to specific additional regulatory requirements and are required to submit emission inventories. ${ }^{560}$ The Upper Green River Basin, in western Wyoming, which includes Sublette County and parts of Sweetwater and Lincoln Counties, has been the highest emitter of VOCs in the western states that are the subject of this article. ${ }^{561}$ It was designated

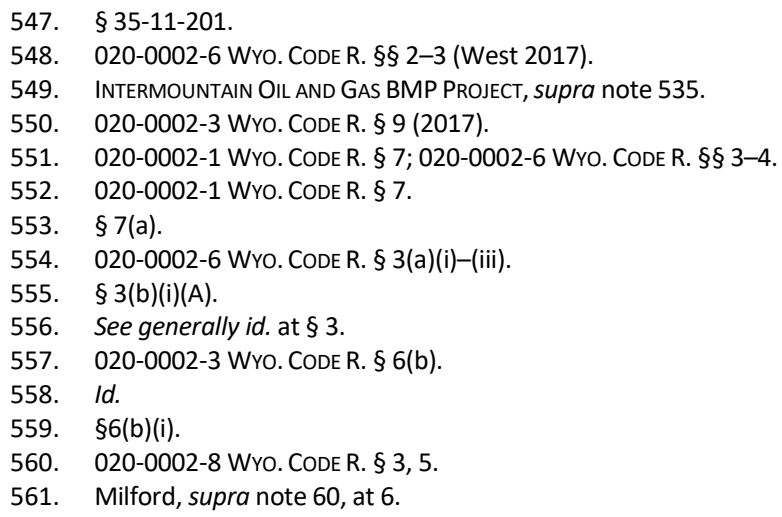


nonattainment for ozone in 2012. ${ }^{562}$ In May 2015, the Wyoming Environmental Quality Council approved a new rule to regulate oil and gas emissions in the Upper Green River Basin (UGRB). ${ }^{563}$ The rule imposes requirements on the oil and gas production facilities and compressor stations located in the UGRB. ${ }^{564}$ Production facilities with VOC emissions equal to or greater than 4 tpy must have controls with ninety-eight percent destruction efficiency. ${ }^{565}$ Fugitive emissions of VOCs also are restricted. ${ }^{566}$

In 2013 Wyoming's Air Quality Division had two permit engineers who processed about 200 construction permits a year for oil and gas facilities. ${ }^{567} \mathrm{It}$ had about 10 emissions inspectors to handle the thousands of well sites in the state. ${ }^{568}$

\section{STATE TAXATION OF OIL AND GAS OPERATIONS}

Approximately thirty-one states have a tax on the extraction of oil and gas. ${ }^{569}$ These states with oil and gas resources have a conflicting relationship with the industry. On the one hand, they regulate the industry, and the more stringent the regulations the greater the effect on the viability of the industry. On the other hand, the states are partners with the industry based on their use of the taxation power to share in the industry's profits. Western states that have a robust oil and gas industry depend on the taxes generated by these businesses for much of their states' revenue. The most important tax is the severance tax or production tax. For example, in 2013, when petroleum prices were high, severance tax collections were $\$ 2,460$ million in North Dakota, \$870 million in Wyoming, \$710 million in New Mexico, \$280 million in Montana, \$150 million in Colorado, \$110 million in Utah, and $\$ 40$ million in California. ${ }^{570}$ Unfortunately, these revenues are subject to the boom and bust nature of the industry. For example, in the San Juan Basin of New Mexico in June 2014, when oil was about $\$ 90$ a barrel the value of the oil sold was $\$ 84,520$ and the taxes paid to the state and local governments was $\$ 5,961 . .^{571}$ Less than a year later, in February 2015, oil was selling for about $\$ 38$ a barrel. ${ }^{572}$ The value of the oil sold dropped to $\$ 28,120$ and the taxes paid dropped to $\$ 1,993 .{ }^{573}$ In 2008 New Mexico's revenue from oil and natural gas was $\$ 1,227,668,013$; in 2010 , it dropped to $\$ 804,337,303.574$

562. Air Quality Designations for the 2008 Ozone National Ambient Air Quality Standards, 77 Fed. Reg. 30,157 (May 21, 2012) (to be codified at 40 C.F.R. pt. 81).

563. 020.0002-8 WYO. CODE R. § 1.

564. $\S 6$.

565. $\S 6(c)(i)(A)$.

566. $\S 6(\mathrm{~g})$.

567. Milford, supra note 60, at 19.

568. Id.

569. Colo. Gen. Assembly, Severance Tax, https://leg.colorado.gov/agencies/legislative-councilstaff/severance-tax (last visited Jan. 9, 2018).

570. Jonathan Thompson, The Winter of Oil's Discontent, 47 HIGH COUNTRY NEWS 12, 17 (2015).

571. Id. at 19.

572. Id.

573. Id.

RES.

574. Richard Anklam \& Deborah Seligman, Oil and Natural Gas Taxing in New Mexico, N.M. TAX INST., 
There is a significant difference in the state tax rates applicable to the oil and gas industry. The oil and gas production tax rate is $11.7 \%$ in Wyoming, $11.2 \%$ in North Dakota, 7.6\% in Montana, 6.9\% in New Mexico, 6.8\% in Colorado, and 3.3\% in Utah. ${ }^{575}$ However, focusing on the production tax rate can be misleading. Some states apply the tax rate to a subset of production, and some states impose multiple taxes. ${ }^{576}$ States may allow local governments to tax oil and gas operations through property taxes, which shifts the benefits of taxation to the areas most impacted by the industry. ${ }^{577}$ There is evidence that state-level taxes are two-thirds higher in states that exclude oil and gas wells from local property taxes. ${ }^{578}$ Taxes can be imposed on the value of the oil and gas or can be imposed on the amount of production. ${ }^{579}$ One approach to enable comparison of production taxes among states is to compare the severance tax dollars received by the state to the Btu value of the fuel produced. ${ }^{580}$ In 2013 the dollars per MMBtu received was $\$ 0.01$ for California, \$0.10 for Colorado, \$0.47 for New Mexico, \$0.13 for Utah, and \$0.24 for Wyoming. ${ }^{581}$ However, this only shows the effect of one of the taxes.

In Utah, there are three taxes or fees on the oil and gas industry. ${ }^{582}$ There is a conservation fee of 0.002 multiplied by the value of oil and gas produced and saved, sold, or transported from the field in Utah. ${ }^{583}$ There is a severance tax with sliding scale rates based on the value of the oil and gas. ${ }^{584}$ It is $3 \%$ for the first $\$ 13$ of value per barrel for oil and $5 \%$ for the value above $\$ 13 .{ }^{585}$ For natural gas, the tax is $3 \%$ for the first $1.50 \mathrm{Mcf}$ and $5 \%$ for the value above 1.50 Mcf. ${ }^{586}$ The law provides various exemptions and tax credits. ${ }^{587}$ There is also a county ad valorem property tax that varies by county. ${ }^{588}$

In Wyoming, two taxes are imposed. ${ }^{589}$ There is a severance tax of up to $6 \%$ of the fair market value of the oil or gas produced. ${ }^{590}$ There is also an ad valorem tax on the value of the oil or gas produced in the prior year, which varies because it

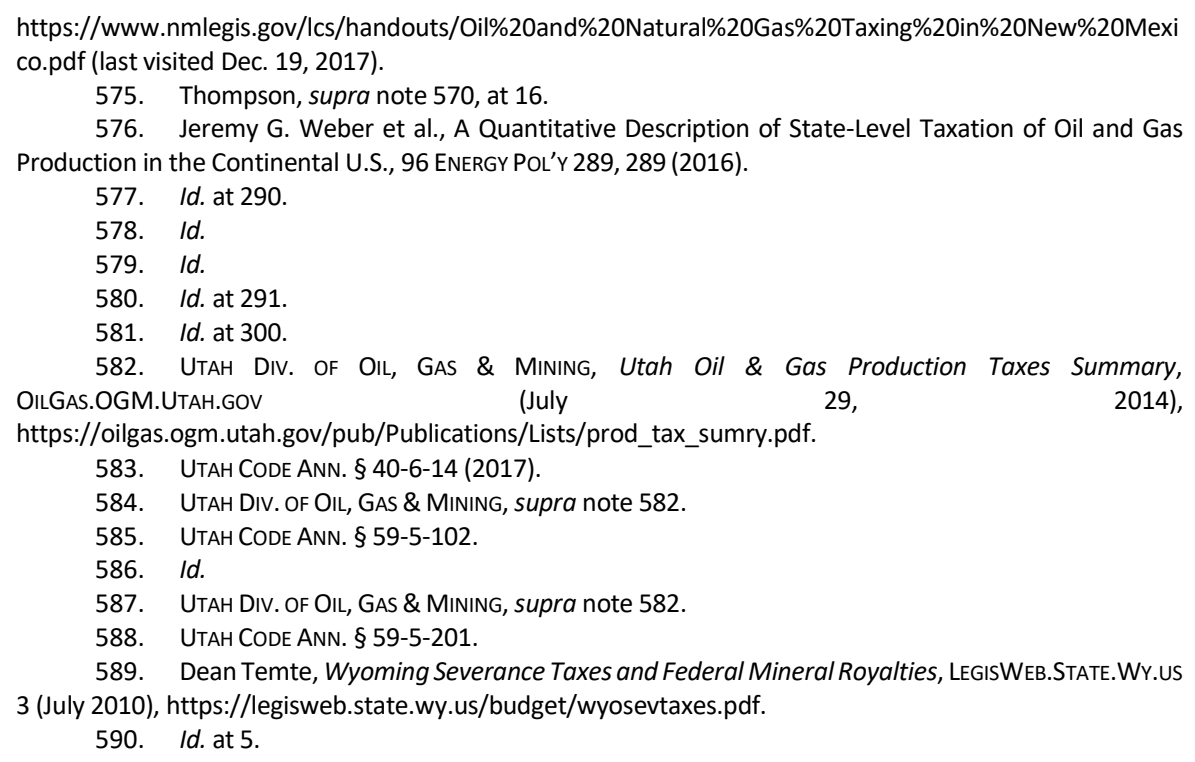


includes county and local taxes. ${ }^{591}$ Colorado has the second lowest effective severance tax at $1.7 \%$ of the nine Western states..$^{592}$ Only Utah has a lower rate. ${ }^{593}$

Colorado has a severance tax based on gross income that increases from $2 \%$ to $5 \%$ for income of $\$ 300,000$ and over. ${ }^{594}$ In 2015 , Colorado firms paid a little over half what Wyoming firms paid on nearly identical production because of Colorado's generous deductions and tax credits. ${ }^{595}$ Montana imposes an oil and gas production tax that varies between $9 \%$ and $14.8 \%$ for qualified natural gas production and between $9 \%$ and $12.5 \%$ for primary oil production. ${ }^{596}$ North Dakota imposes a $5 \%$ tax on the gross value at the well of oil produced in the state with some adjustments if the price of oil increases substantially. ${ }^{597}$ Natural gas in fiscal year 2017 is taxed at $\$ 0.0601$ per Mcf of gas produced. ${ }^{598}$ New Mexico has a natural gas processing tax that is imposed on the amount of MMBtus of natural gas delivered to a processing plant. ${ }^{599}$ It has an oil and gas production equipment ad valorem tax based on $27 \%$ of the value of products for each production unit with a rate based on the local property tax. ${ }^{600}$ It has an oil and gas severance tax of $3.75 \%$ of the value of the oil or natural gas, an oil and gas conservation tax, and an oil and gas emergency school tax, and an oil and gas ad valorem production tax. ${ }^{601}$ These taxes change each year. ${ }^{602}$

\section{CONCLUSION}

The Republican Party supports policies that increase domestic energy production including production on public lands. ${ }^{603}$ Methane, the subject of this article is an important GHG, but the Party's official position is climate change "is far from this nation's most pressing national security issue. This is the triumph of extremism over common sense, and Congress must stop it." ${ }^{\prime 604}$ The Party proposes

591. Id. at 18.

592. Christopher N. Osher, Tale of Two States: North Dakota has \$4 Billion Saved from Oil and Gas Taxes; Colorado has Almost None, DeNVER POST (Jan. 27, 2017), http://www.denverpost.com/2017/01/27/ndakota-4-billion-saved-oil-gas-colorado-none/.

593. Id.

594. Colo. Rev. Stat. AnN. § 39-29-105 (West 2017).

595. Osher, supra note 592.

596. MONT. LEGIS. FISCAL DIV., Montana's OIL AND GAS PRODUCtION TAX (2014).

597. N.D. OfF. OF St. TAX COMm'R, Oil \& Gas Severance Tax, ND.Gov, http://www.nd.gov/tax/oilgas/ (last visited Jan. 9, 2018).

598. N.D. Off. St. TAX COMm'R, North Dakota Gas Tax Rate, ND.Gov, https://www.nd.gov/tax/user/businesses/formspublications/oil--gas-severance-tax/forms-instructions/north-dakota-gas-tax-rate (last visited Jan. 9, 2018).

599. N.M. TAX'N \& Revenue Dep'T, Oil and Gas Tax Programs, NeWMeXICo.Gov, http://realfile.tax.newmexico.gov/rpd-41140.pdf (last visited Jan. 9, 2018).

600. Id.

601. Jacquelyn Pless, Oil and Gas Severance Taxes: States Work to Alleviate Pressures Amid the Natural Gas Boom, NAT'L CONF. ST. LEGISLATURES, http://www.ncsl.org/research/energy/oil-and-gasseverance-taxes.aspx (last updated Feb. 2012).

602. N.M. TAX'N \&REVENUE DEP'T, supra note 599.

603. The 2016 Republican Party Platform, GOP.COM, 19, https://prod-cdnstatic.gop.com/static/home/data/platform.pdf (last visited Jan. 9, 2018).

604. Id. at 20 . 
"to shift responsibility for environmental regulation from the federal bureaucracy to the states and to transform the EPA into an independent bipartisan commission similar to the Nuclear Regulatory Commission." 605 President Trump appointed Scott Pruitt as the EPA's Administrator. ${ }^{606}$ When Administrator Pruitt was Oklahoma's Attorney General he worked closely with the energy industry to prevent the environmental regulation of oil and gas, which included opposing the regulation of methane. ${ }^{607}$ Because both President Trump and Administrator Pruitt seek to expand oil and gas production ${ }^{608}$ and have a well-documented antipathy toward efforts to protect the environment, it will be difficult to develop more stringent federal regulations to control methane in this administration. ${ }^{609}$

The Republican majority in Congress has used the Congressional Review Act (CRA) to override regulations enacted to protect the environment. ${ }^{610}$ The CRA allows Congress, by a majority vote to strike down recently issued regulations, which then prevents agencies from issuing substantially similar regulations without express authorization from Congress. ${ }^{611}$ By April 3, 2017, the CRA has been used to nullify fourteen rules issued under the Obama Administration. ${ }^{612}$ However, as previously discussed, the effort to use the CRA to rescind the Methane Rule was rejected by the Senate. ${ }^{613}$ Other more established regulations that are not subject to the CRA can be expected to be the focus of new rulemaking efforts to weaken the regulations. Thus, it is likely that oil and gas producing states will play a more important role in the control of air emissions, including GHG emissions, from the oil

605. Id. at 21.

606. Chris Mooney et al., Trump Names Scott Pruitt, Oklahoma Attorney General Suing EPA on Climate Change, to Head the EPA, WASH. POST (Dec. 8, 2016), https://www.washingtonpost.com/news/energy-environment/wp/2016/12/07/trump-names-scott-

pruitt-oklahoma-attorney-general-suing-epa-on-climate-change-to-head-theepa/?utm_term=.012ffd79975b.

607. Lee Logan \& Abby Smith, Emails Detail Pruitt's Prior Coordination with Fossil Groups on EPA Rules, INSIDE EPA: CLEAN AIR REP. (Feb. 22, 2017), https://insideepa.com/daily-news/emails-detail-pruittsprior-coordination-fossil-groups-epa-rules.

608. Alan Kovski, Interior to Step Up Pace of Oil, Gas Leasing on Federal Land, Dally Env't Rep. (BNA), June 30. 2017, BLOOMBERg LAW, DEN Issue No. 125.

609. Dawn Reeves, Trump, Pruitt Comments May Harm Them in Court Fight over CPP Rollback, CleAN AIR ReP., Apr. 6, 2017, 2017 WLNR 10470029; Justin Worland, Trump Takes Aim at Obama's Climate Legacy, TIME (Mar. 30, 2017), http://time.com/4718023/trump-aim-obama-climate-legacy/; Public Citizen, Trump's Corporate Cabinet, http://www.corporatecabinet.org (last visited Jan. 9, 2018).

610. 5 U.S.C. $\S \S 801-808$ (2012). It was enacted in 1996 as section 251 of the Contract with America Advancement Act of 1996, Pub. L. No. 104-121, 110 Stat. 847 (1996). Until 2017, it had been successfully invoked only once in 2001. Susan E. Dudley, CRAzy After All These Years: Extending the Reach of the Congressional Review Act, FORBES (Mar. 7, 2017), https://www.forbes.com/sites/susandudley/2017/03/07/crazy-after-all-these-years-extending-the-reachof-the-congressional-review-act/\#78f661b124b8.

611. David Rosen, The Republican War on Regulation, 37 PUB. CITIZEN News 1, 8 (Mar./Apr. 2017), https://cw.citizen.org/sites/default/files/pc_news_issues/2017/mar-apl/files/assets/basic-

html/index.html; U.S. Envtl. Prot. Agency, Summary of the Congressional Review Act, EvntL. Prot. Agency, https://www.epa.gov/laws-regulations/summary-congressional-review-act (last updated Aug. 2, 2016); Ari Natter, Congressional Clock Running Out to Repeal Obama Regulations, ENERGY \& CLIMATE ReP. (BNA), Apr. 10, 2017, BLOOMBERG LAW, ECR Issue No. 67.

612. Lisa Lambert, Democrats in U.S. Senate Try to Slow Republican Deregulation, REUTERS (May 16, 2017), https://www.reuters.com/article/us-usa-congress-regulation-exclusive/democrats-in-u-ssenate-try-to-slow-republican-deregulation-idUSKCN18C1T5.

613. See supra Section III.H. 
and gas industry. This can be expected to result in significantly differing levels of regulation and enforcement among the states. 